\title{
LEVEL II SCOUR ANALYSIS FOR BRIDGE 42 (NEWFTH00350042) on TOWN HIGHWAY 35, crossing STRATTON HILL BROOK, NEWFANE, VERMONT
}

Open-File Report 98-404

Prepared in cooperation with

VERMONT AGENCY OF TRANSPORTATION

and

FEDERAL HIGHWAY ADMINISTRATION

U.S. Department of the Interior

U.S. Geological Survey

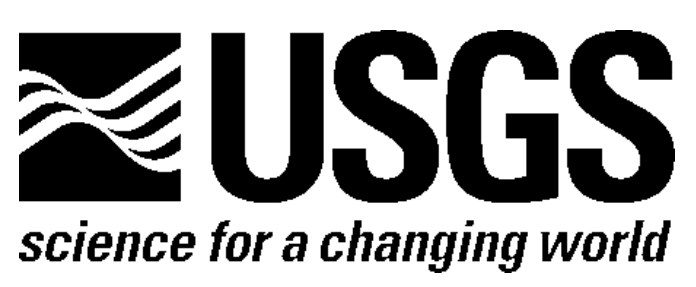


LEVEL II SCOUR ANALYSIS FOR

BRIDGE 42 (NEWFTH00350042) on

TOWN HIGHWAY 35, crossing

STRATTON HILL BROOK,

NEWFANE, VERMONT

By EMILY C. WILD and MICHAEL A. IVANOFF

U.S. Geological Survey

Open-File Report 98-404

Prepared in cooperation with

VERMONT AGENCY OF TRANSPORTATION

and

FEDERAL HIGHWAY ADMINISTRATION 


\title{
U.S. DEPARTMENT OF THE INTERIOR BRUCE BABBITT, Secretary
}

\author{
U.S. GEOLOGICAL SURVEY
}

Thomas J. Casadevall, Acting Director

For additional information write to:

District Chief

U.S. Geological Survey 361 Commerce Way

Pembroke, NH 03275-3718
Copies of this report may be purchased from:

U.S. Geological Survey

Branch of Information Services

Open-File Reports Unit

Box 25286

Denver, CO 80225-0286 


\section{CONTENTS}

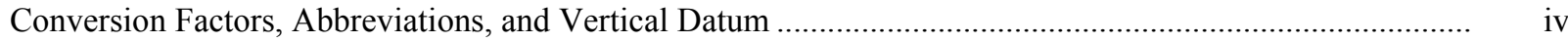

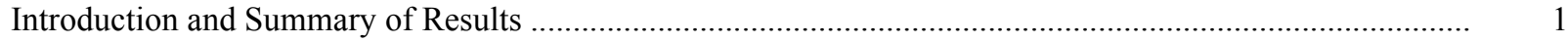

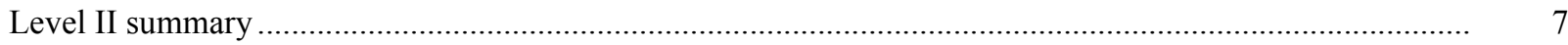

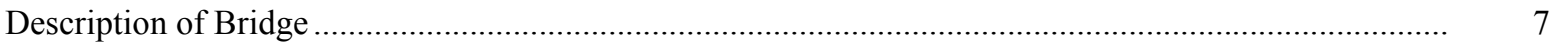

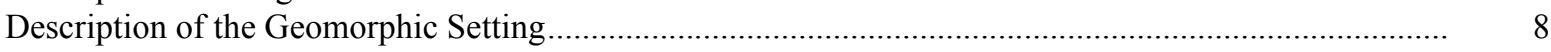

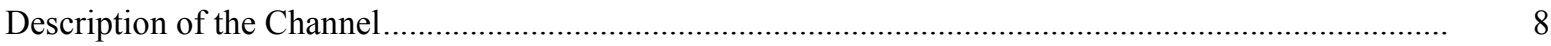

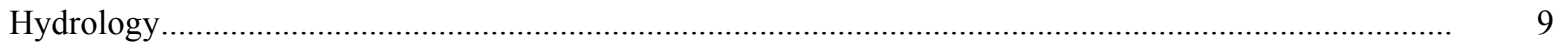

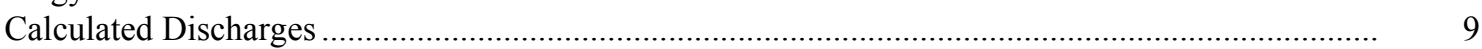

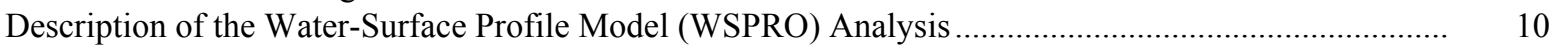

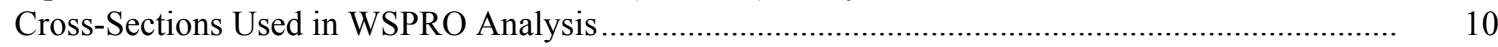

Data and Assumptions Used in WSPRO Model ........................................................................ 11

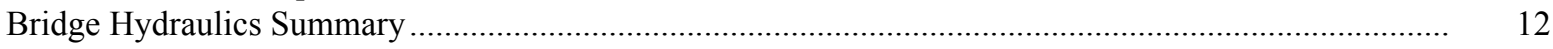

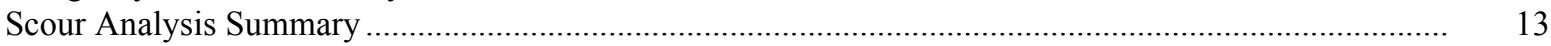

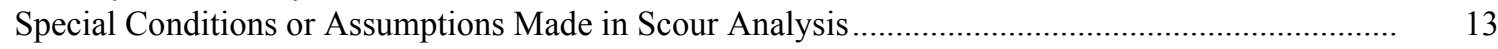

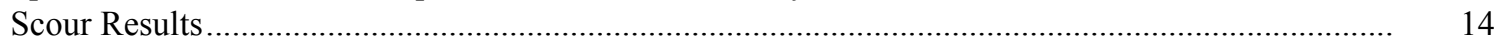

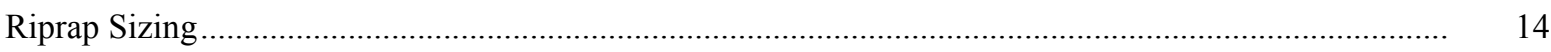

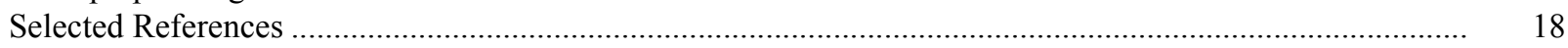

Appendices:

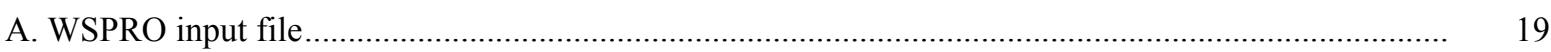

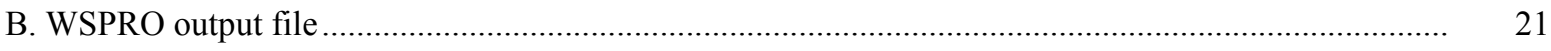



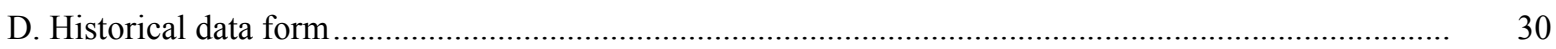

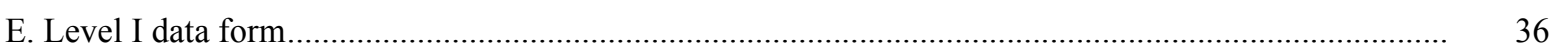

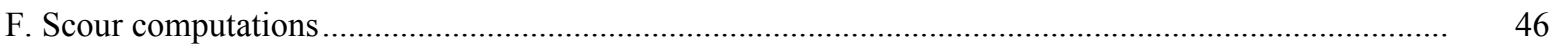

\section{FIGURES}

1. Map showing location of study area on USGS 1:25,000 scale map

2. Map showing location of study area on Vermont Agency of Transportation town highway map

3. Structure NEWFTH00350042 viewed from upstream (August 20, 1996)

4. Downstream channel viewed from structure NEWFTH00350042 (August 20, 1996)............................ 5

5. Upstream channel viewed from structure NEWFTH00350042 (August 20, 1996)................................ 6

6. Structure NEWFTH00350042 viewed from downstream (August 20, 1996).

7. Water-surface profiles for the 100- and 500-year discharges at structure

NEWFTH00350042 on Town Highway 35, crossing Stratton Hill Brook,

Newfane, Vermont.

8. Scour elevations for the 100- and 500-year discharges at structure

NEWFTH00350042 on Town Highway 35, crossing Stratton Hill Brook,

Newfane, Vermont.

\section{TABLES}

1. Remaining footing/pile depth at abutments for the 100-year discharge at structure

NEWFTH00350042 on Town Highway 35, crossing Stratton Hill Brook,

Newfane, Vermont

2. Remaining footing/pile depth at abutments for the 500-year discharge at structure

NEWFTH00350042 on Town Highway 35, crossing Stratton Hill Brook,

Newfane, Vermont 


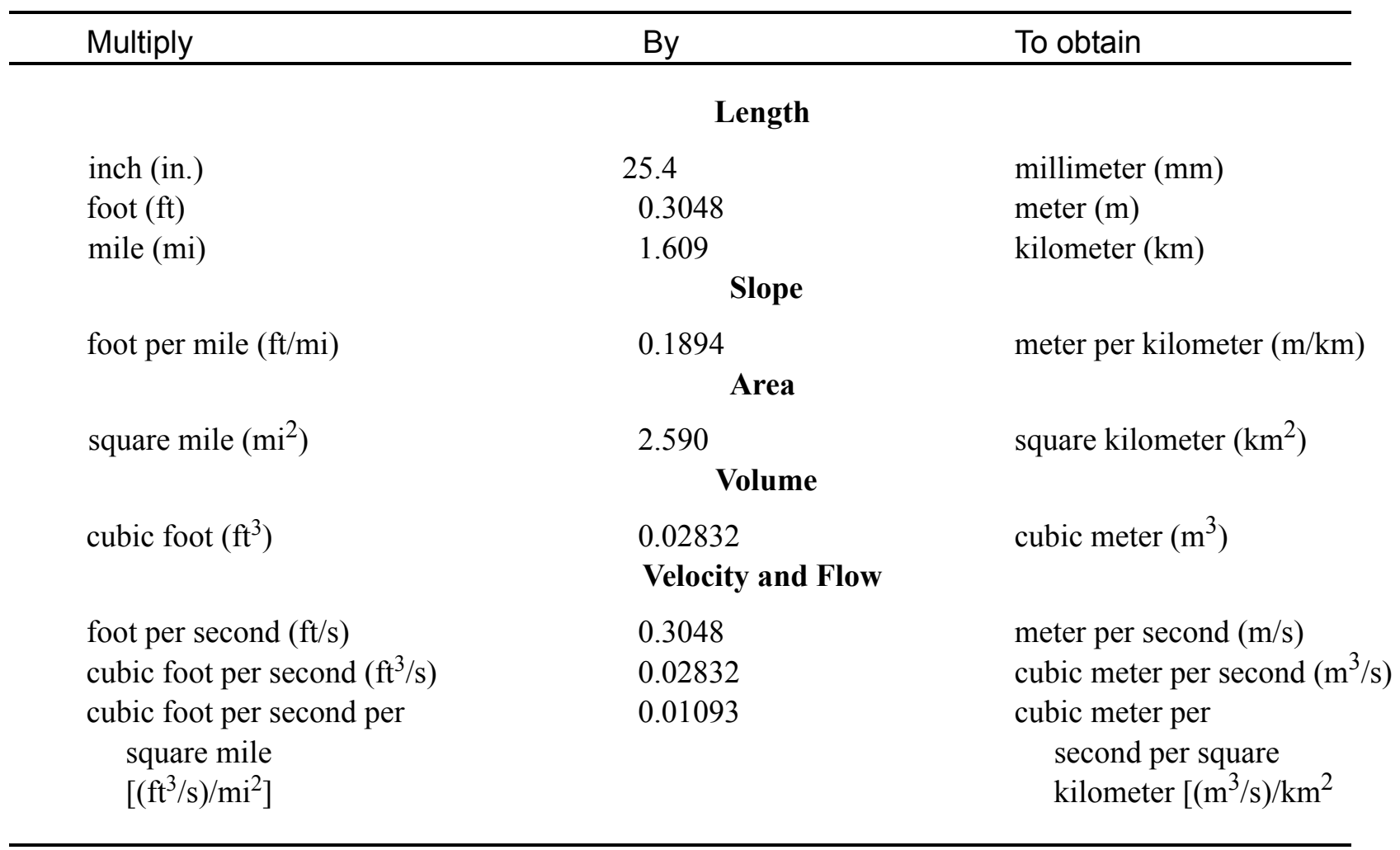

\section{OTHER ABBREVIATIONS}

$\begin{array}{lrlr}\mathrm{BF} & \text { bank full } & \text { LWW } & \text { left wingwall } \\ \mathrm{cfs} & \text { cubic feet per second } & \text { Max } & \text { maximum } \\ \mathrm{D}_{50} & \text { median diameter of bed material } & \text { MC } & \text { main channel } \\ \mathrm{DS} & \text { downstream } & \text { RAB } & \text { right abutment } \\ \mathrm{elev} & \text { elevation } & \text { RABUT } & \text { face of right abutment } \\ \mathrm{f} / \mathrm{p} & \text { flood plain } & \text { RB } & \text { right bank } \\ \mathrm{ft} & \text { square feet } & \text { ROB } & \text { right overbank } \\ \mathrm{ft} / \mathrm{ft} & \text { feet per foot } & \text { RWW } & \text { right wingwall } \\ \mathrm{FEMA} & \text { Federal Emergency Management Agency } & \text { TH } & \text { town highway } \\ \mathrm{FHWA} & \text { Federal Highway Administration } & \text { UB } & \text { under bridge } \\ \mathrm{JCT} & \text { junction } & \text { US } & \text { upstream } \\ \text { LAB } & \text { left abutment } & \text { USGS } & \text { United States Geological Survey } \\ \text { LABUT } & \text { face of left abutment } & \text { VTAOT } & \text { Vermont Agency of Transportation } \\ \text { LB } & \text { left bank } & \text { WSPRO } & \text { water-surface profile model } \\ \text { LOB } & \text { left overbank } & \text { yr } & \text { year }\end{array}$

In this report, the words "right" and "left" refer to directions that would be reported by an observer facing downstream. Sea level: In this report, "sea level" refers to the National Geodetic Vertical Datum of 1929-- a geodetic datum derived from a general adjustment of the first-order level nets of the United States and Canada, formerly called Sea Level Datum of 1929.

In the appendices, the above abbreviations may be combined. For example, USLB would represent upstream left bank. 


\title{
LEVEL II SCOUR ANALYSIS FOR BRIDGE 42 (NEWFTH00350042) ON TOWN HIGHWAY 35, CROSSING STRATTON HILL BROOK, NEWFANE, VERMONT
}

\author{
By Emily C. Wild and Michael A. Ivanoff
}

\section{INTRODUCTION AND SUMMARY OF RESULTS}

This report provides the results of a detailed Level II analysis of scour potential at structure NEWFTH00350042 on Town Highway 35 crossing Stratton Hill Brook, Newfane, Vermont (figures 1-8). A Level II study is a basic engineering analysis of the site, including a quantitative analysis of stream stability and scour (FHWA, 1993). Results of a Level I scour investigation also are included in appendix $\mathrm{E}$ of this report. A Level I investigation provides a qualitative geomorphic characterization of the study site. Information on the bridge, gleaned from Vermont Agency of Transportation (VTAOT) files, was compiled prior to conducting Level I and Level II analyses and is found in appendix D.

The site is in the New England Upland section of the New England physiographic province in southeastern Vermont. The $1.16-\mathrm{mi}^{2}$ drainage area is in a predominantly rural and forested basin. In the vicinity of the study site, the surface cover is forested.

In the study area, Stratton Hill Brook has an incised, striaght channel with a slope of approximately $0.1 \mathrm{ft} / \mathrm{ft}$, an average channel top width of $36 \mathrm{ft}$ and an average bank height of $8 \mathrm{ft}$. The channel bed material ranges from gravel to boulders with a median grain size $\left(\mathrm{D}_{50}\right)$ of $121 \mathrm{~mm}(0.396 \mathrm{ft})$. The geomorphic assessment at the time of the Level I and Level II site visit on August 20, 1996, indicated that the reach was stable.

The Town Highway 34 crossing of Stratton Hill Brook is a 34-ft-long, one-lane bridge consisting of a 32-foot steel-beam span (Vermont Agency of Transportation, written communication, April 6, 1995). The opening length of the structure parallel to the bridge face is $30.8 \mathrm{ft}$. The bridge is supported by vertical, concrete abutments with upstream wingwalls. The channel is skewed approximately 20 degrees to the opening while the computed opening-skew-to-roadway is 15 degrees.

During the Level I assessment, it was observed that the right abutment footing was exposed 1.5 feet. The only scour protection measure at the site was type-1 stone fill (less than 12 inches diameter) along the downstream left bank. Additional details describing conditions at the site are included in the Level II Summary and appendices D and E. 
Scour depths and recommended rock rip-rap sizes were computed using the general guidelines described in Hydraulic Engineering Circular 18 (Richardson and Davis, 1995) for the 100- and 500-year discharges. Total scour at a highway crossing is comprised of three components: 1) long-term streambed degradation; 2) contraction scour (due to accelerated flow caused by a reduction in flow area at a bridge) and; 3) local scour (caused by accelerated flow around piers and abutments). Total scour is the sum of the three components. Equations are available to compute depths for contraction and local scour and a summary of the results of these computations follows.

Contraction scour for all modelled flows was zero ft. Abutment scour ranged from 2.3 to 3.3 $\mathrm{ft}$. The worst-case abutment scour occurred at the 500-year discharge. Additional information on scour depths and depths to armoring are included in the section titled "Scour Results". Scoured-streambed elevations, based on the calculated scour depths, are presented in tables 1 and 2. A cross-section of the scour computed at the bridge is presented in figure 8. Scour depths were calculated assuming an infinite depth of erosive material and a homogeneous particle-size distribution.

It is generally accepted that the Froehlich equation (abutment scour) gives "excessively conservative estimates of scour depths" (Richardson and Davis, 1995, p. 46). Usually, computed scour depths are evaluated in combination with other information including (but not limited to) historical performance during flood events, the geomorphic stability assessment, existing scour protection measures, and the results of the hydraulic analyses. Therefore, scour depths adopted by VTAOT may differ from the computed values documented herein. 


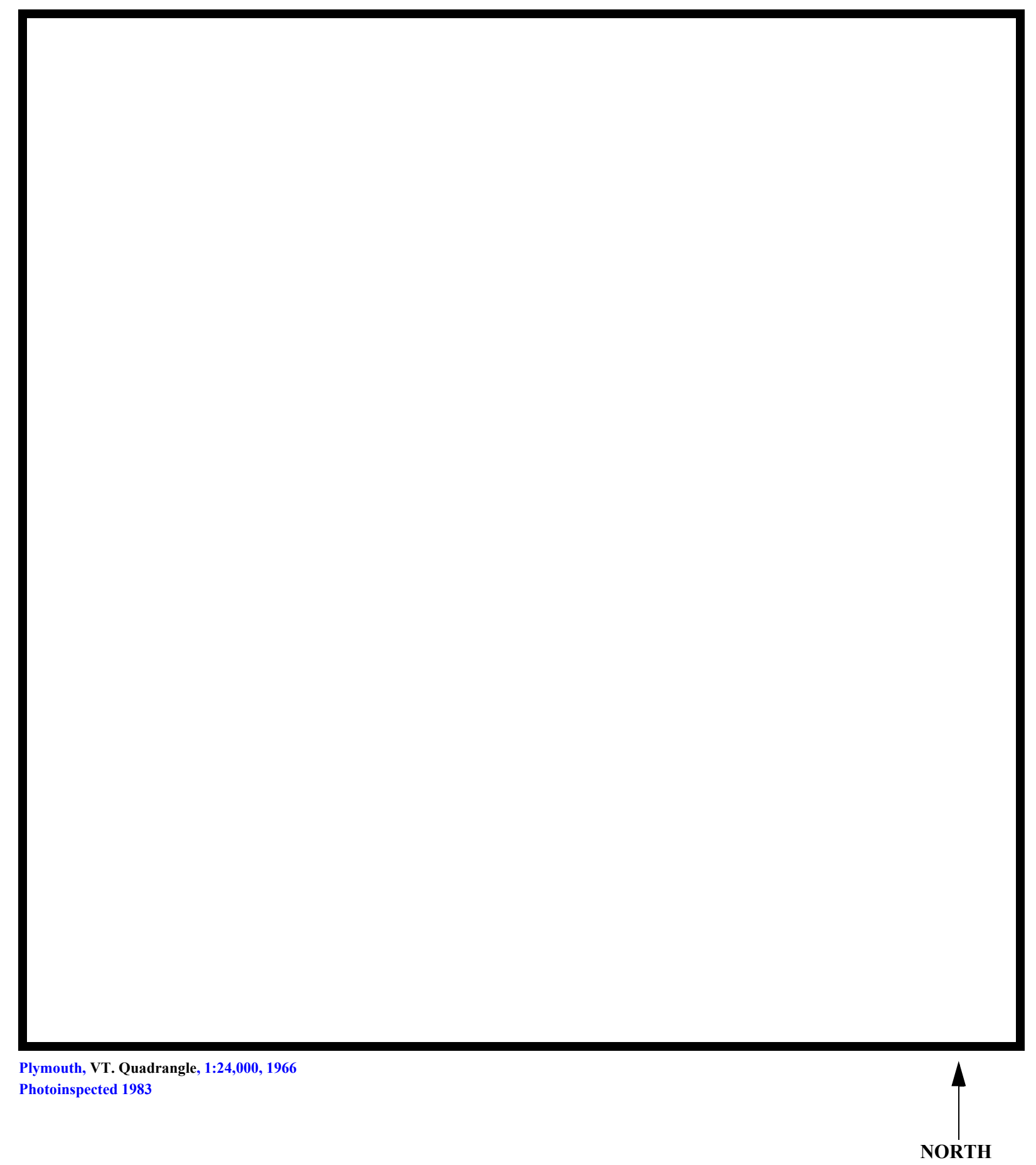

Figure 1. Location of study area on USGS 1:24,000 scale map. 
Figure 2. Location of study area on Vermont Agency of Transportation town highway map. 

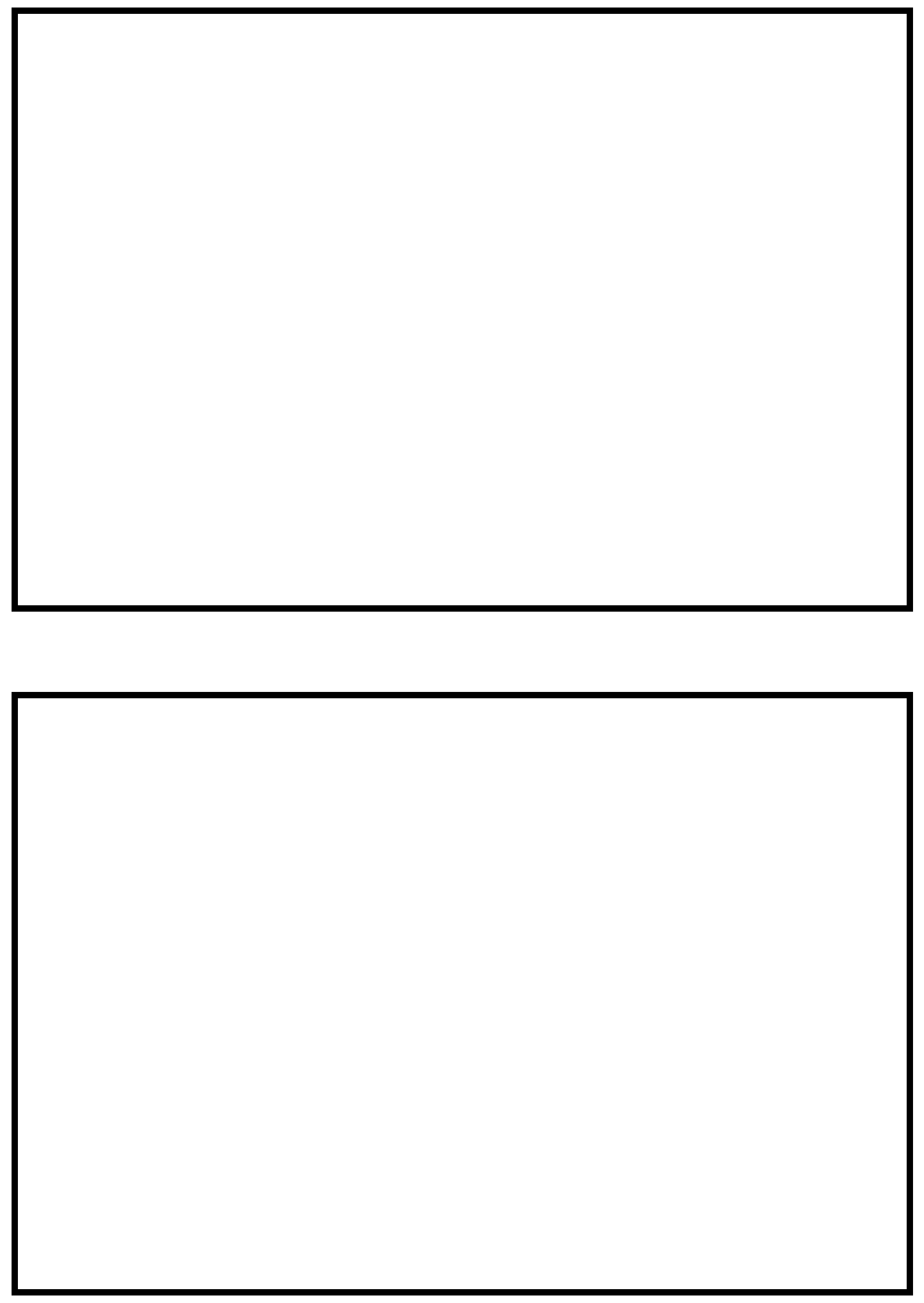




\section{LEVEL II SUMMARY}

\begin{tabular}{llllll} 
Structure Number & NEWFTH00350042 & & \multicolumn{3}{c}{ Stratton Hill Brook } \\
Stream & & & & \\
County & Windham & Road & TH 35 & District & 2
\end{tabular}

\section{Description of Bridge}



Abutments and wingwalls are concrete. The right

abutment footing is exposed $1.5 \mathrm{ft}$ at the downstream end.

Yes

Angle

Debris accumulation on bridge at time of Level I or Level II site visit:

Is bridge skewed to flood flow according to No survey?

\begin{tabular}{|c|c|c|c|}
\hline & $\begin{array}{l}\text { Date of insnortion } \\
\underline{8 / 20 / 96}\end{array}$ & $\begin{array}{l}\text { Percent of almanal } \\
\text { blocked inortzontatly }\end{array}$ & $\begin{array}{l}\text { Percent of } 0 \text { - n...el } \\
\text { blocked verticatty }\end{array}$ \\
\hline evel I & $8 / 20 / 96$ & 0 & 0 \\
\hline $\begin{array}{l}\text { Level II } \\
\text { leaning }\end{array}$ & \multicolumn{3}{|c|}{ Moderate. There is some debris on the channel banks and trees are } \\
\hline
\end{tabular}

No features were observed, 8/20/96.

Doscriho anv, fonturos noar ar at tho hridoo that mav, affort flou, (includo ahsorvation dato) 


\section{Description of the Geomorphic Setting}

General topography The channel is located within a moderately sloped valley.

Geomorphic conditions at bridge site: downstream (DS), upstream (US)

Date of inspection $\quad 8 / 20 / 96$

DS left: $\quad$ Steep channel bank with a moderately sloped overbank.

DS right: $\quad$ Steep channel bank with a moderately sloped overbank.

US left: $\quad$ Steep channel bank with a moderately sloped overbank.

US right: Steep channel bank with a moderately sloped overbank.

\section{Description of the Channel}

\begin{tabular}{|c|c|c|c|}
\hline & & & 8 \\
\hline Average top width & $\begin{array}{l}\boldsymbol{f t} \\
\text { Cobbles/Boulders }\end{array}$ & Average depth & Cobbles/Boulders \\
\hline
\end{tabular}

Predominant bed material

Bank material

Sinuous but stable

with non-alluvial channel boundaries.

$8 / 20 / 96$

Vegetative co 1 Trees and brush.

DS left: $\quad$ Trees and brush with Town Highway 35 adjacent to the channel bank.

DS right: $\quad$ Trees and brush with Town Highway 35 adjacent to the channel bank.

US left: $\quad$ Trees and brush.

US right: $\quad$ Yes

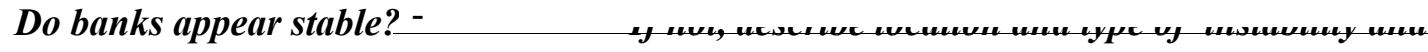

date of observatton.

No obstructions were

observed, 8/20/96.

Describe any obstructions in channel and date of observation. 


\section{Hydrology}

Drainage area $\frac{1.16}{\mathrm{mi}^{2}}$

Percentage of drainage area in physiographic provinces: (approximate)

Physiographic province/section New England/ New England Upland
Percent of drainage area 100

Is drainage area considered rural or urban? — Rural _ Describe any significant urbanization:

Is there a USGS gage on the stream of interest?

No

USGS gage description

USGS gage number

Gage drainage area $\mathrm{mi}^{2}$

Is there a lake/p

\begin{tabular}{llrl}
440 & \multicolumn{2}{c}{ Calculated Discharges } & 680 \\
0100 & $f t^{3} / s$ & $Q 500$ & $f t^{3} / s$
\end{tabular}

The 100-year and 500-year discharges are the

median yalues taken from the range defined by several empirical flood frequency curves

(Benson, 1962; Johnson and Tasker, 1974; FHWA, 1983; Potter, 1957a\&b; Talbot, 1887). Each curve was extended graphically to the 500 -year event. 


\section{Description of the Water-Surface Profile Model (WSPRO) Analysis}

Datum for WSPRO analysis (USGS survey, sea level, VTAOT plans)

USGS survey

Datum tie between USGS survey and VTAOT plans

None

Description of reference marks used to determine USGS datum. $\quad$ RM1 is a chiseled X on top of the upstream right wingwall (elev. $499.56 \mathrm{ft}$, arbitrary survey datum). RM2 is a chiseled X on top of the upstream end of the left abutment (elev. $501.05 \mathrm{ft}$, arbitrary survey datum).

\section{Cross-Sections Used in WSPRO Analysis}

\begin{tabular}{|c|c|c|c|}
\hline${ }^{1}$ Cross-section & $\begin{array}{c}\text { Section } \\
\text { Reference } \\
\text { Distance } \\
\text { (SRD) in feet }\end{array}$ & $\begin{array}{l}{ }^{2} \text { Cross-section } \\
\text { development }\end{array}$ & Comments \\
\hline EXIT1 & -33 & 1 & Exit section \\
\hline DSBRG & 0 & 1 & $\begin{array}{l}\text { Downstream bridge sec- } \\
\text { tion and road grade sec- } \\
\text { tion }\end{array}$ \\
\hline USBRG & 17 & 1 & $\begin{array}{l}\text { Upstream bridge section } \\
\text { and road grade section }\end{array}$ \\
\hline APPR1 & 40 & 2 & $\begin{array}{l}\text { Modelled Approach sec- } \\
\text { tion (Templated from } \\
\text { APTEM) }\end{array}$ \\
\hline APTEM & 49 & 1 & $\begin{array}{l}\text { Approach section as sur- } \\
\text { veyed (Used as a tem- } \\
\text { plate) }\end{array}$ \\
\hline
\end{tabular}

${ }^{1}$ For location of cross-sections see plan-view sketch included with Level I field form, Appendix E. For more detail on how cross-sections were developed see WSPRO input file. 


\section{Data and Assumptions Used in WSPRO Model}

Hydraulic analyses of the reach were done by use of the Federal Highway Administration's WSPRO step-backwater computer program (Shearman and others, 1986, and Shearman, 1990). The analyses reported herein reflect conditions existing at the site at the time of the study. Furthermore, in the development of the model it was necessary to assume no accumulation of debris or ice at the site. Results of the hydraulic model are presented in the Bridge Hydraulic Summary, appendix B, and figure 7.

Channel roughness factors (Manning's " $n$ ") used in the hydraulic model were estimated using field inspections at each cross section following the general guidelines described by Arcement and Schneider (1989). Final adjustments to the values were made during the modelling of the reach. Channel " $n$ " values for the reach ranged from 0.075 to 0.080 , and overbank " $n$ " values ranged from 0.055 to 0.065 .

Critical depth at the exit section (EXIT1) was assumed as the starting water surface. Normal depth was computed by use of the slope-conveyance method outlined in the user's manual for WSPRO (Shearman, 1990) which resulted in a supercritical solution, but within 0.3 feet of critical depth. The slope used was $0.0950 \mathrm{ft} / \mathrm{ft}$, which was calculated from thalweg points surveyed downstream of the bridge.

The surveyed approach section (APTEM) was moved along the approach channel slope $(0.1034 \mathrm{ft} / \mathrm{ft})$ to establish the modelled approach section (APPR1), one bridge length upstream of the upstream face as recommended by Shearman and others (1986). This location provides a consistent method for determining scour variables.

For all modelled flows, the bridge was not a significant constriction in the channel. The WSPRO bridge routines failed to find a solution which balanced the total discharge and energy at the APPRO section with the sum of the discharges and energy over the roadway and through the bridge opening. Therefore, the bridge was ignored, and the channel at the bridge was combined with the roadway cross-section to represent a full valley cross section at the bridge location. 


\section{Bridge Hydraulics Summary}

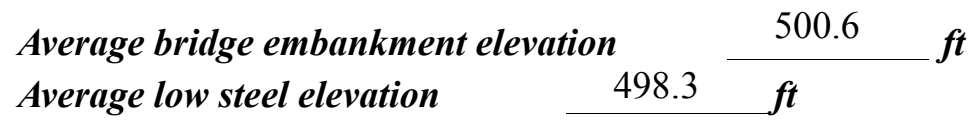

100-year discharge $\quad 440 \quad \mathrm{ft}^{3} / \mathrm{s}$

Water-surface elevation in bridge opening $\quad 493.4 \quad f t$

Road overtopping? ___ No Discharge over road ___-- $\mathrm{ft}^{3} / \mathrm{s}$

\begin{tabular}{llll} 
Area of flow in bridge opening & 53 & $\boldsymbol{f t}^{2}$ \\
\cline { 2 - 3 } Average velocity in bridge opening & 8.3 & $\mathbf{f t} / \mathbf{s}$
\end{tabular}

$\begin{array}{llll}\text { Maximum WSPRO tube velocity at bridge } & 10.9 \mathrm{ft} / \mathrm{s}\end{array}$

Water-surface elevation at Approach section with bridge N/A

Water-surface elevation at Approach section without bridge $\quad 496.6$

Amount of backwater caused by bridge N/A it

500-year discharge $\quad 680 \quad \mathrm{ft}^{3} / \mathrm{s}$

Water-surface elevation in bridge opening

$494.3 \boldsymbol{f t}$

Road overtopping? ___ No Discharge over road ___ -- ${ }_{i} i^{3} / \mathrm{s}$

Area of flow in bridge opening

Average velocity in bridge opening 69 $\mathrm{ft}^{2}$ $9.8 \mathrm{ft} / \mathrm{s}$

Maximum WSPRO tube velocity at bridge 12.9 /s

Water-surface elevation at Approach section with bridge

Water-surface elevation at Approach section without bridge

Amount of backwater caused by bridge N/A , $t$

N/A

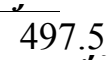

Incipient overtopping discharge ___ -- $\mathrm{ft}^{3} / \mathrm{s}$

Water-surface elevation in bridge opening $\quad--\quad t$

Area of flow in bridge opening

$\begin{array}{llll}-- & f t^{2} & \\ & -- & f t / s & f t / s\end{array}$

Maximum WSPRO tube velocity at bridge $f t / s$

Water-surface elevation at Approach section with bridge Water-surface elevation at Approach section without bridge


Amount of backwater caused by bridge $-\quad$ it 


\section{Scour Analysis Summary}

\section{Special Conditions or Assumptions Made in Scour Analysis}

Scour depths were computed using the general guidelines described in Hydraulic Engineering Circular 18 (Richardson and Davis, 1995). Scour depths were calculated assuming an infinite depth of erosive material and a homogeneous particle-size distribution. The results of the scour analyses for the 100- and 500-year discharges are presented in tables 1 and 2 and the scour depths are shown graphically in figure 8 .

Contraction scour for the 100-year and 500-year discharges was computed by use of the Laursen clear-water contraction scour equation (Richardson and Davis, 1995, p. 32, equation 20). Variables for the Laursen clear-water contraction scour equation include the discharge through the bridge, the width of the channel at the bridge, and the median grain size of the channel bed material.

Abutment scour was computed by use of the Froehlich equation (Richardson and Davis, 1995, p. 48, equation 28). Variables for the Froehlich equation include the Froude number of the flow approaching the embankments, the length of the embankment blocking flow, and the depth of flow approaching the embankment less any roadway overtopping. For this case, the embankments do not block flow. Therefore, the depth of flow at each abutment was assumed to be the depth of abutment scour.

Because the influence of scour processes on the embankment material is uncertain, the scour depth at the vertical left abutment wall is unknown. Therefore, the total scour depth shown in figure 8 for the left abutment was applied for the entire embankment below the elevation at the toe of the embankment. 


\section{Scour Results}

Contraction scour:

Main channel

Live-bed scour

Clear-water scour

Depth to armoring

Left overbank

Right overbank

Local scour:

Abutment scour

Left abutment

Right abutment

Pier scour

Pier 1

Pier 2

Pier 3

2.4

2.3-


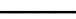

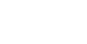

100-year discharge

500-year discharge

(Scour depths in feet)

Incipient

overtopping discharge 


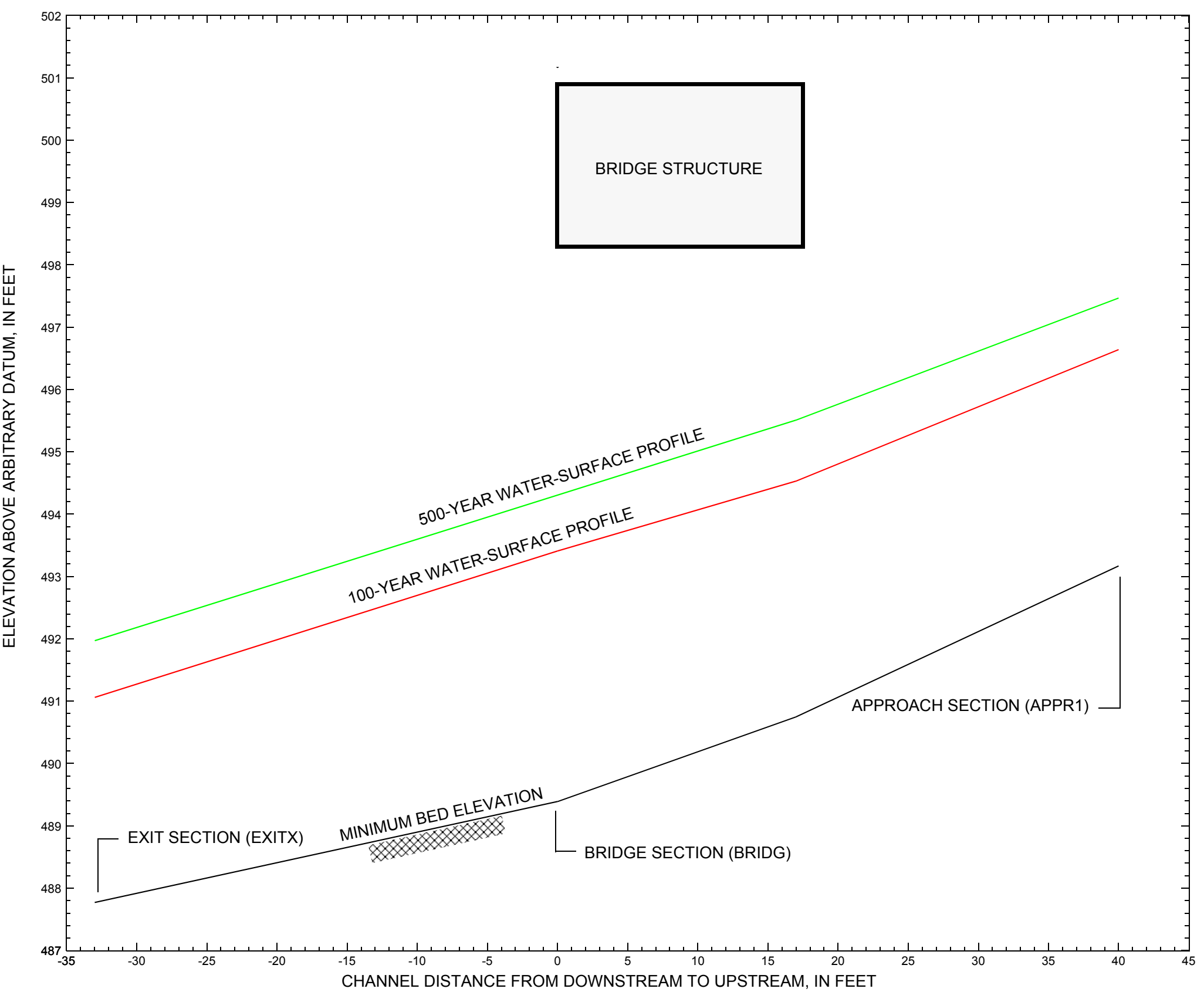

Figure 7. Water-surface profiles for the 100- and 500-year discharges at structure NEWFTH00350042 on Town Highway 35, crossing Stratton Hill Brook, Newfane, Vermont. 


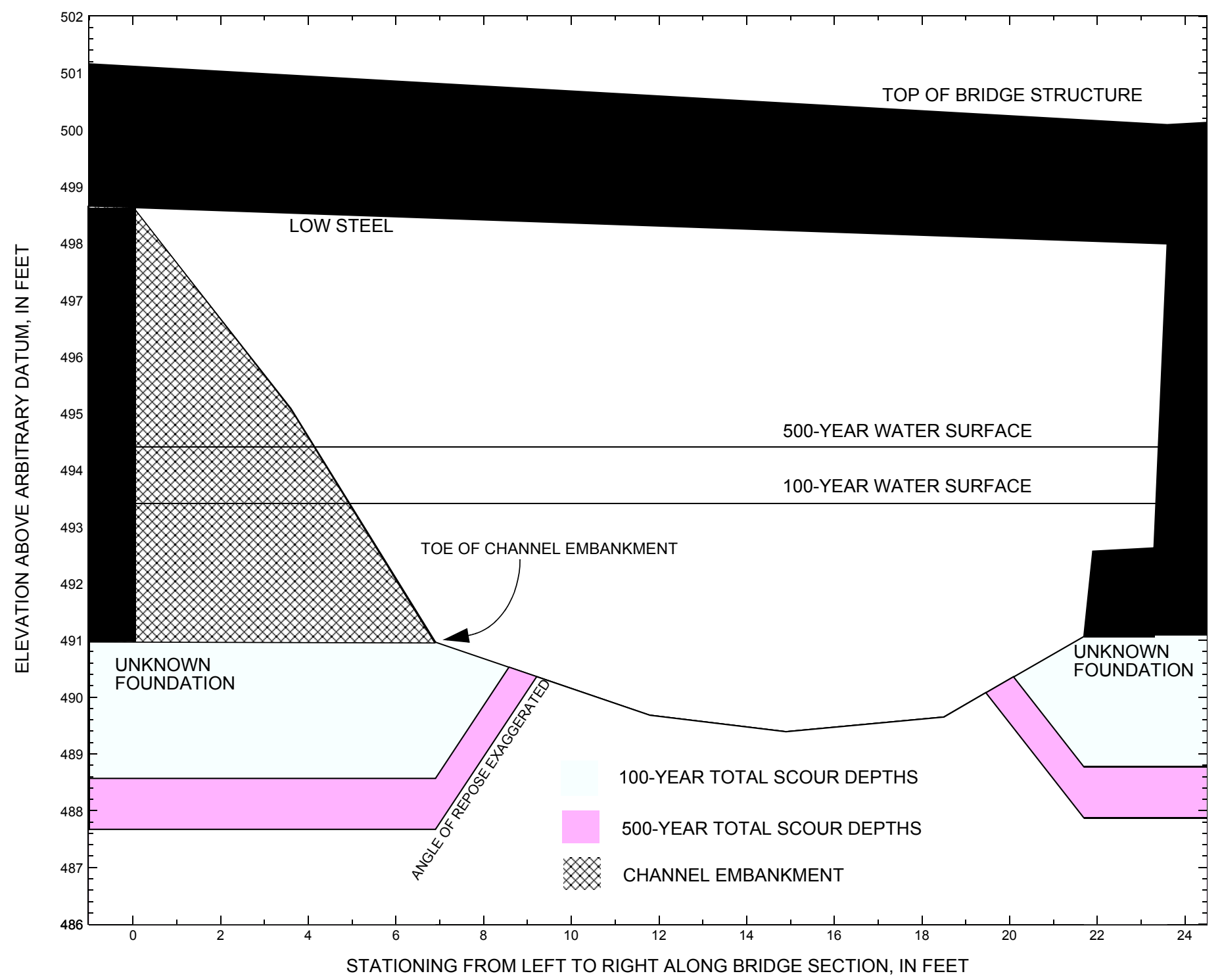

Figure 8. Scour elevations for the 100- and 500-year discharges at structure NEWFTH00350042 on Town Highway 35, crossing Stratton Hill Brook, Newfane, Vermont. 
Table 1. Remaining footing/pile depth at abutments for the 100-year discharge at structure NEWFTH00350042 on Town Highway 35, crossing Stratton Hill Brook, Newfane, Vermont.

[VTAOT, Vermont Agency of Transportation; --, no data]

\begin{tabular}{|c|c|c|c|c|c|c|c|c|c|c|c|}
\hline Description & Station $^{1}$ & $\begin{array}{c}\text { VTAOT } \\
\text { minimum } \\
\text { low-chord } \\
\text { elevation } \\
\text { (feet) }\end{array}$ & $\begin{array}{c}\text { Surveyed } \\
\text { minimum } \\
\text { low-chord } \\
\text { elevation } \\
\text { (feet) }\end{array}$ & $\begin{array}{c}\text { Bottom of } \\
\text { footing/pile } \\
\text { elevation }{ }^{2} \\
\text { (feet) }\end{array}$ & $\begin{array}{c}\text { Channel } \\
\text { elevation at } \\
\text { abutment/ } \\
\text { pier }^{2} \\
\text { (feet) }\end{array}$ & $\begin{array}{l}\text { Contraction } \\
\text { scour depth } \\
\text { (feet) }\end{array}$ & $\begin{array}{l}\text { Abutment } \\
\text { scour } \\
\text { depth } \\
\text { (feet) }\end{array}$ & $\begin{array}{l}\text { Pier } \\
\text { scour } \\
\text { depth } \\
\text { (feet) }\end{array}$ & $\begin{array}{l}\text { Depth of } \\
\text { total scour } \\
\text { (feet) }\end{array}$ & $\begin{array}{c}\text { Elevation of } \\
\text { scour }^{2} \\
\text { (feet) }\end{array}$ & $\begin{array}{c}\text { Remaining } \\
\text { footing/pile } \\
\text { depth } \\
\text { (feet) }\end{array}$ \\
\hline \multicolumn{12}{|c|}{100 -year. discharge is 440 cubic-feet per second } \\
\hline Left abutment & 0.0 & -- & 498.6 & -- & -- & -- & -- & -- & -- & 488.6 & -- \\
\hline $\begin{array}{c}\text { Channel } \\
\text { embankment } \\
\text { toe }\end{array}$ & 6.9 & -- & -- & -- & 491.0 & 0.0 & 2.4 & -- & 2.4 & 488.6 & -- \\
\hline Right abutment & 23.6 & -- & 498.0 & -- & 491.1 & 0.0 & 2.3 & -- & 2.3 & 488.8 & -- \\
\hline
\end{tabular}

1.Measured along the face of the most constricting side of the bridge.

2.Arbitrary datum for this study.

Table 2. Remaining footing/pile depth at abutments for the 500-year discharge at structure NEWFTH00350042 on Town Highway 35, crossing Stratton Hill Brook, Newfane, Vermont.

[VTAOT, Vermont Agency of Transportation; --, no data]

\begin{tabular}{|c|c|c|c|c|c|c|c|c|c|c|c|}
\hline Description & Station $^{1}$ & $\begin{array}{l}\text { VTAOT } \\
\text { minimum } \\
\text { low-chord } \\
\text { elevation } \\
\text { (feet) }\end{array}$ & $\begin{array}{c}\text { Surveyed } \\
\text { minimum } \\
\text { low-chord } \\
\text { elevation } \\
\text { (feet) }\end{array}$ & $\begin{array}{c}\text { Bottom of } \\
\text { footing/pile } \\
\text { elevation }{ }^{2} \\
\text { (feet) }\end{array}$ & $\begin{array}{c}\text { Channel } \\
\text { elevation at } \\
\text { abutment/ } \\
\text { pier }^{2} \\
\text { (feet) }\end{array}$ & $\begin{array}{l}\text { Contraction } \\
\text { scour depth } \\
\text { (feet) }\end{array}$ & $\begin{array}{l}\text { Abutment } \\
\text { scour } \\
\text { depth } \\
\text { (feet) }\end{array}$ & $\begin{array}{l}\text { Pier } \\
\text { scour } \\
\text { depth } \\
\text { (feet) }\end{array}$ & $\begin{array}{l}\text { Depth of } \\
\text { total scour } \\
\text { (feet) }\end{array}$ & $\begin{array}{c}\text { Elevation of } \\
\text { scour }^{2} \\
\text { (feet) }\end{array}$ & $\begin{array}{c}\text { Remaining } \\
\text { footing/pile } \\
\text { depth } \\
\text { (feet) }\end{array}$ \\
\hline \multicolumn{12}{|c|}{500 -year. discharge is 680 cubic-feet per second } \\
\hline Left abutment & 0.0 & -- & 498.6 & -- & -- & -- & -- & -- & 3.3 & 487.7 & -- \\
\hline $\begin{array}{c}\text { Channel } \\
\text { embankment } \\
\text { toe }\end{array}$ & 6.9 & -- & -- & -- & 491.0 & 0.0 & 3.3 & -- & 3.3 & 487.7 & \\
\hline Right abutment & 23.6 & -- & 498.0 & -- & 491.1 & 0.0 & 3.2 & -- & 3.2 & 487.9 & -- \\
\hline
\end{tabular}

1.Measured along the face of the most constricting side of the bridge.

2.Arbitrary datum for this study. 


\section{SELECTED REFERENCES}

Arcement, G.J., Jr., and Schneider, V.R., 1989, Guide for selecting Manning's roughness coefficients for natural channels and flood plains: U.S. Geological Survey Water-Supply Paper 2339, 38 p.

Barnes, H.H., Jr., 1967, Roughness characteristics of natural channels: U.S. Geological Survey Water-Supply Paper 1849,213 p.

Benson, M. A., 1962, Factors Influencing the Occurrence of Floods in a Humid Region of Diverse Terrain: U.S. Geological Survey WaterSupply Paper 1580-B, 64 p.

Brown, S.A. and Clyde, E.S., 1989, Design of riprap revetment: Federal Highway Administration Hydraulic Engineering Circular No. 11, Publication FHWA-IP-89-016, 156 p.

Federal Highway Administration, 1983, Runoff estimates for small watersheds and development of sound design: Federal Highway Administration Report FHWA-RD-77-158.

Federal Highway Administration, 1993, Stream Stability and Scour at Highway Bridges: Participant Workbook: Federal Highway Administration Report FHWA-HI-91-011.

Froehlich, D.C., 1989, Local scour at bridge abutments in Ports, M.A., ed., Hydraulic Engineering--Proceedings of the 1989 National Conference on Hydraulic Engineering: New York, American Society of Civil Engineers, p. 13-18.

Hayes, D.C.,1993, Site selection and collection of bridge-scour data in Delaware, Maryland, and Virginia: U.S. Geological Survey WaterResources Investigation Report 93-4017, 23 p.

Interagency Advisory Committee on Water Data, 1982, Guidelines for determining flood flow frequency: U.S. Geological Survey, Bulletin 17B of the Hydrology Subcommittee, 190 p.

Johnson, C.G. and Tasker, G.D.,1974, Progress report on flood magnitude and frequency of Vermont streams: U.S. Geological Survey OpenFile Report 74-130, 37 p.

Lagasse, P.F., Schall, J.D., Johnson, F., Richardson, E.V., Chang, F., 1995, Stream Stability at Highway Structures: Federal Highway Administration Hydraulic Engineering Circular No. 20, Publication FHWA-IP-90-014, 144 p.

Laursen, E.M., 1960, Scour at bridge crossings: Journal of the Hydraulics Division, American Society of Civil Engineers, v. 86, no. HY2, p. 39-53.

Potter, W. D., 1957a, Peak rates of runoff in the Adirondack, White Mountains, and Maine woods area, Bureau of Public Roads

Potter, W. D., 1957b, Peak rates of runoff in the New England Hill and Lowland area, Bureau of Public Roads

Richardson, E.V. and Davis, S.R., 1995, Evaluating scour at bridges: Federal Highway Administration Hydraulic Engineering Circular No. 18, Publication FHWA-IP-90-017, 204 p.

Richardson, E.V., Simons, D.B., and Julien, P.Y., 1990, Highways in the river environment: Federal Highway Administration Publication FHWA-HI-90-016.

Ritter, D.F., 1984, Process Geomorphology: W.C. Brown Co., Debuque, Iowa, 603 p.

Shearman, J.O., 1990, User's manual for WSPRO--a computer model for water surface profile computations: Federal Highway Administration Publication FHWA-IP-89-027, 187 p.

Shearman, J.O., Kirby, W.H., Schneider, V.R., and Flippo, H.N., 1986, Bridge waterways analysis model; research report: Federal Highway Administration Publication FHWA-RD-86-108, 112 p.

Talbot, A.N., 1887, The determination of water-way for bridges and culverts.

U.S. Geological Survey, 1984, Newfane, Vermont 7.5 Minute Series quadrangle map: U.S. Geological Survey Topographic Maps, Scale $1: 25,000$. 


\section{APPENDIX A: \\ WSPRO INPUT FILE}




\section{WSPRO INPUT FILE}

GR

GR

GR

GR

GR

*

$\mathrm{N}$

SA

*

$\mathrm{XS}$

GR

GR

GR

GR

GR

*

$\mathrm{N}$

SA

\section{*}

XS

GR

GR

GR

GR

GR

*

$\mathrm{N}$

SA

*

$\mathrm{XT}$

GR

GR

GR

GR

*

$\mathrm{XS}$

GT

$\mathrm{N}$

SA

*

HP 1 DSBRG 493.411493 .41

HP 2 DSBRG 493.41 * * 440

$\mathrm{HP} 1$ APPR1 496.641496 .64

HP 2 APPR 1496.64 * 440

$54.9,497.58$

$105.5,507.93$

0.065

0.0

APTEM $49 \quad 0$.

$$
\begin{array}{r}
-78.9, \quad 512.88 \\
5.8, \quad 495.26
\end{array}
$$

$22.4,495.78$

APPR1

0.055

$$
-5.8
$$

0 .

$\begin{array}{rrrr}-16.7,504.10 & -7.9,503.17 & 0.0,499.95 \\ 17.1,488.07 & 19.2,487.77 & 22.7,487.89 \\ 27.1,487.88 & 30.9,492.92 & 36.0,495.06 \\ 71.1,497.12 & 74.8,496.04 & 79.2,496.56\end{array}$

0.080

0.065

30.9

$$
-49.7, \quad 504.52
$$

$6.9,490.97$

$21.7,491.07$

$30.8,500.09$

$87.6,504.65$

0.075

0.0

\section{$17 \quad 15$}

$-83.7,515.79$

$0.5,497.79$

$22.5,491.19$

$30.1,500.09$

$68.9,500.13$

0.055

0.0

$-49.7, \quad 504.52$

$10.0,493.61$

$29.2,492.41$

$30.8,500.09$

$87.6,504.65$

$-0.1,501.12$

$11.8,489.68$

$21.9,492.57$

$37.0,499.91$

$110.9,508.61$

$37.0,499.91$

$\mathrm{ECW}$

Date: $02-J A N-98$

$\begin{array}{lll}4 & 7 & 3\end{array}$

$-63.8,506.53$

$11.8,494.59$

$-5.8,502.34$

$0.0,499.62$

$26.6,500.12$

$14.1,494.10$

$0.0,498.63$

$14.9,489.39$

$23.3,492.63$

$50.1,499.44$

$34.2,502.98$

$0.1,499.11$

$21.0,490.75$

$30.0,493.23$

$50.1,499.44$

0.080

0.055

$17.0,494.58$

* 


\section{APPENDIX B: \\ WSPRO OUTPUT FILE}


WSPRO OUTPUT FILE

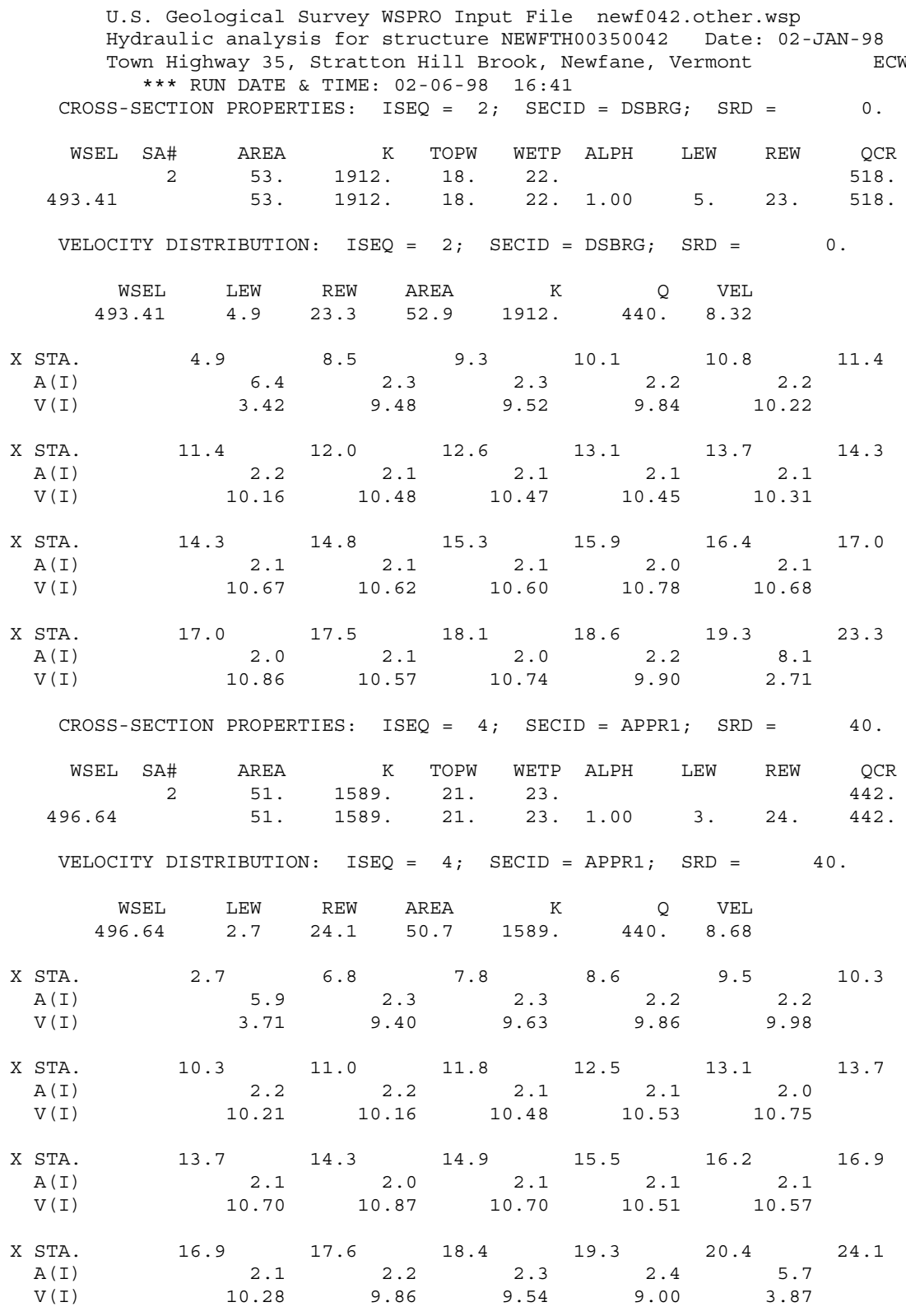


WSPRO OUTPUT FILE (continued)

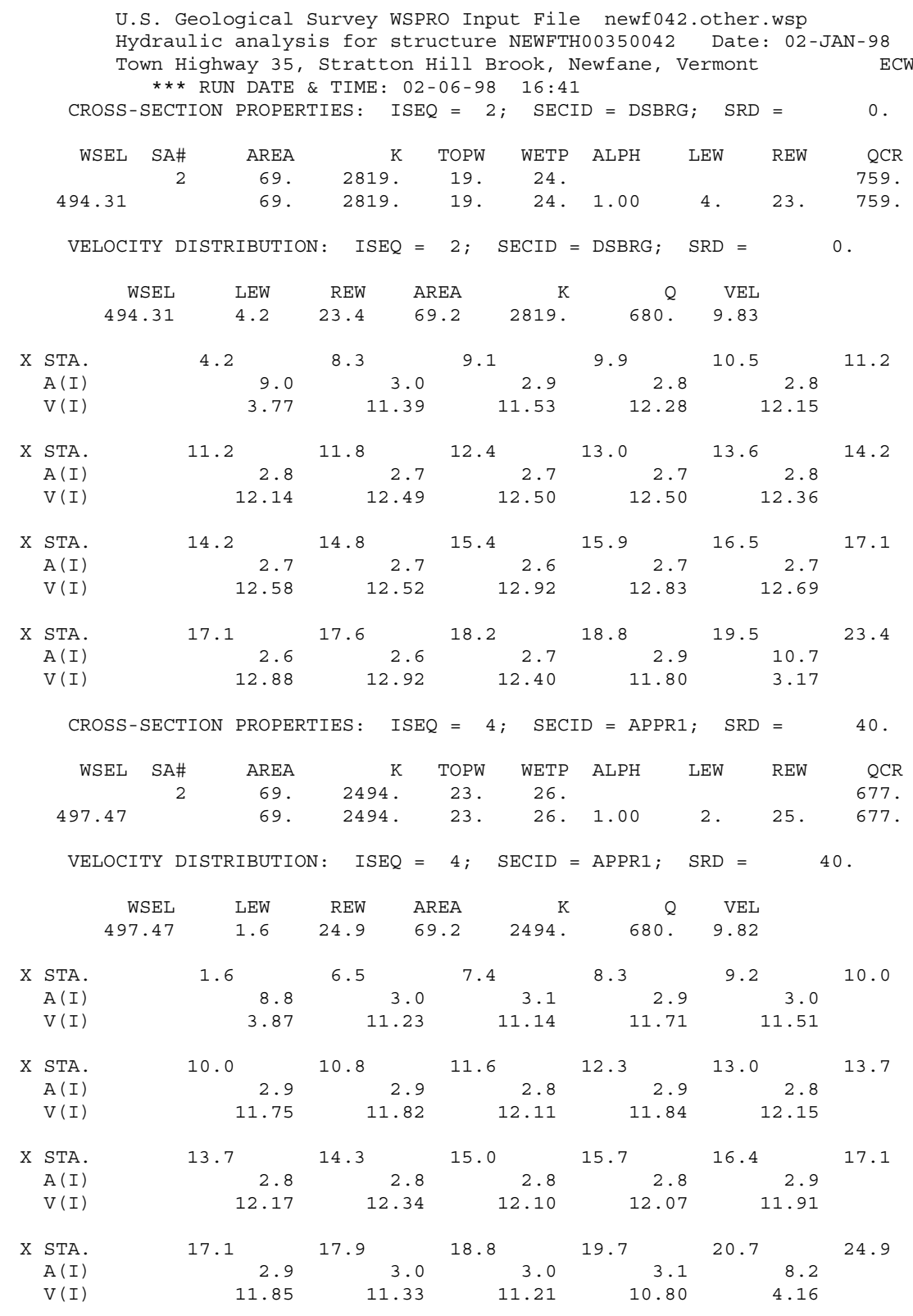


WSPRO OUTPUT FILE (continued)

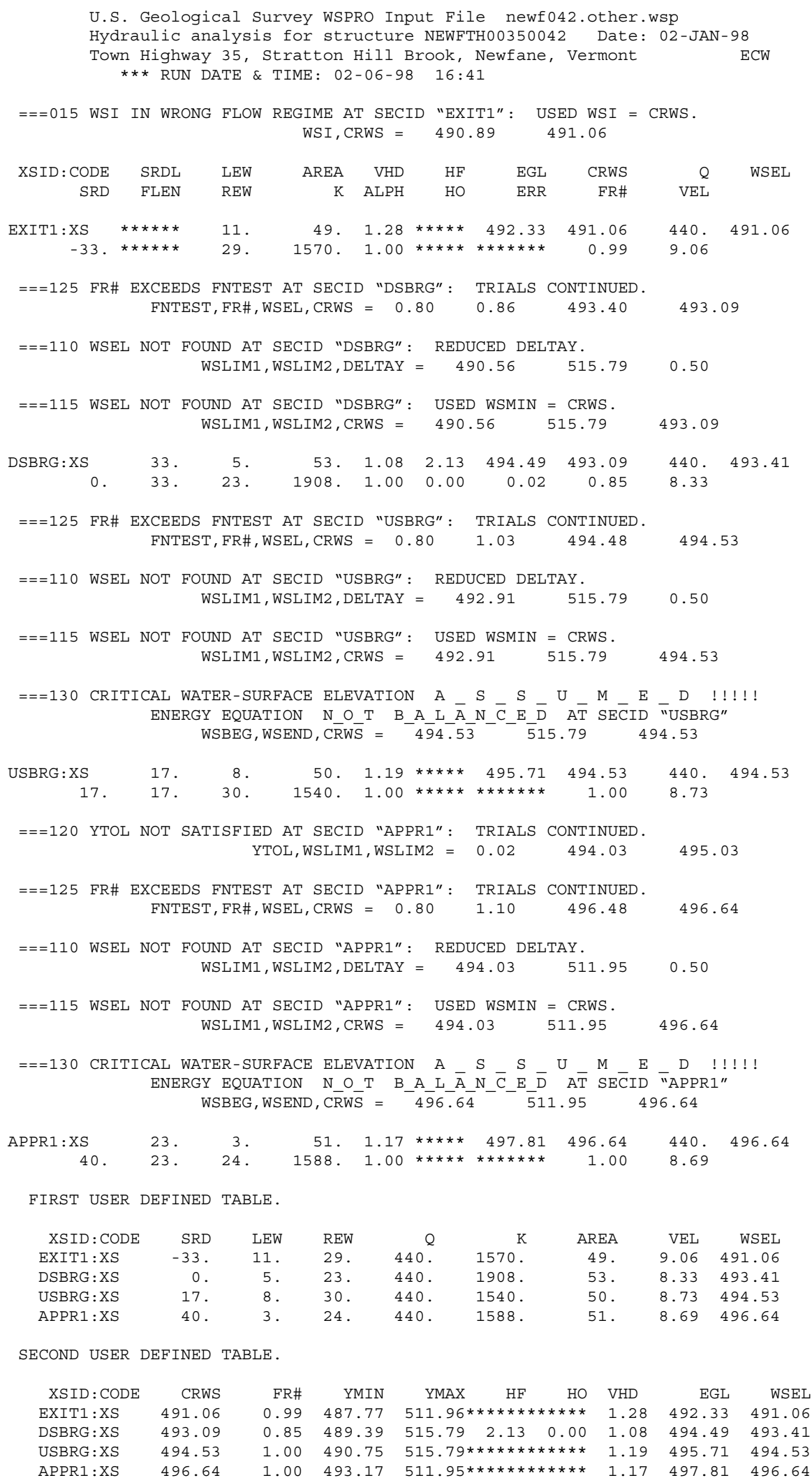


WSPRO OUTPUT FILE (continued)

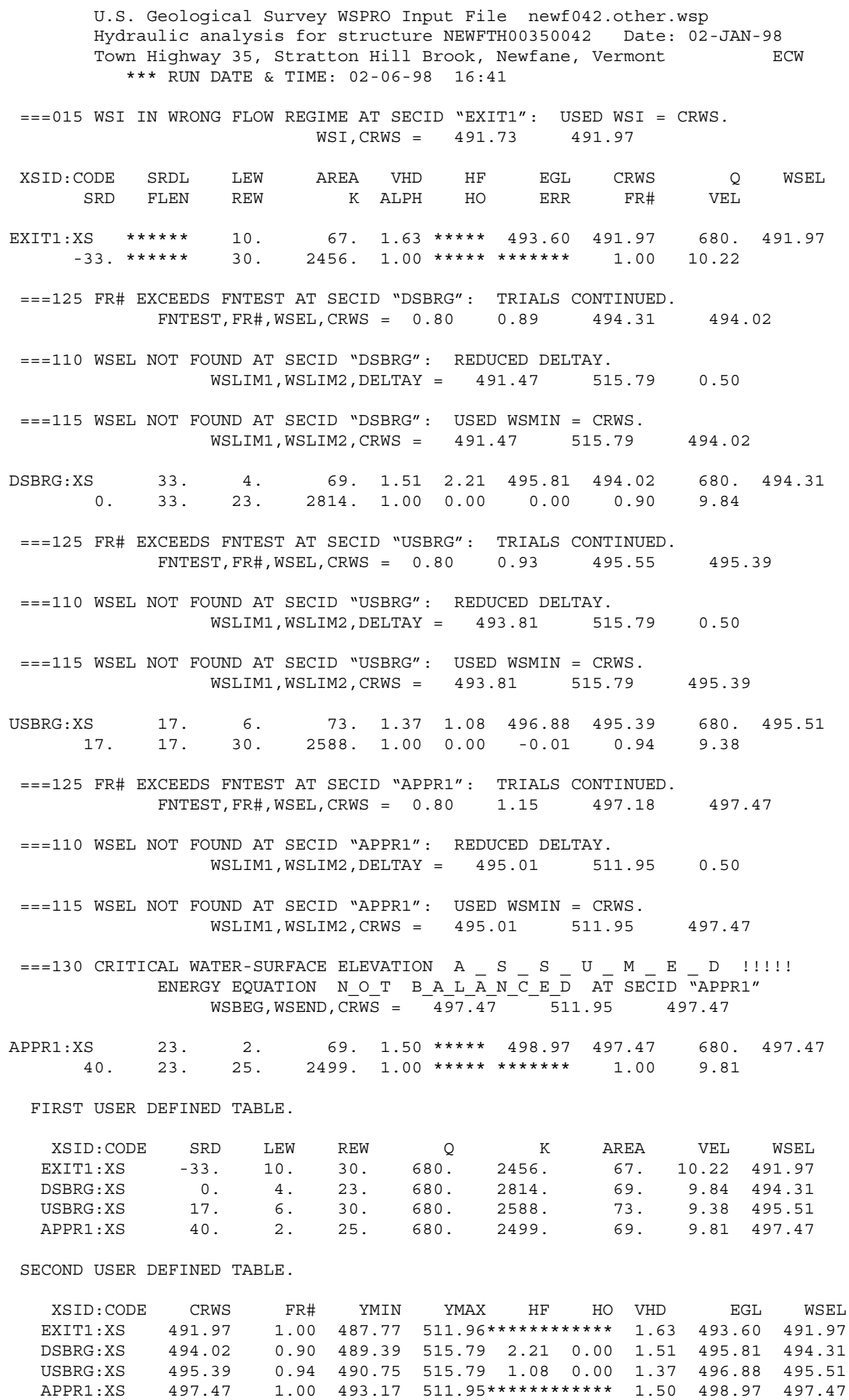




\section{APPENDIX C:}

\section{BED-MATERIAL PARTICLE-SIZE DISTRIBUTION}




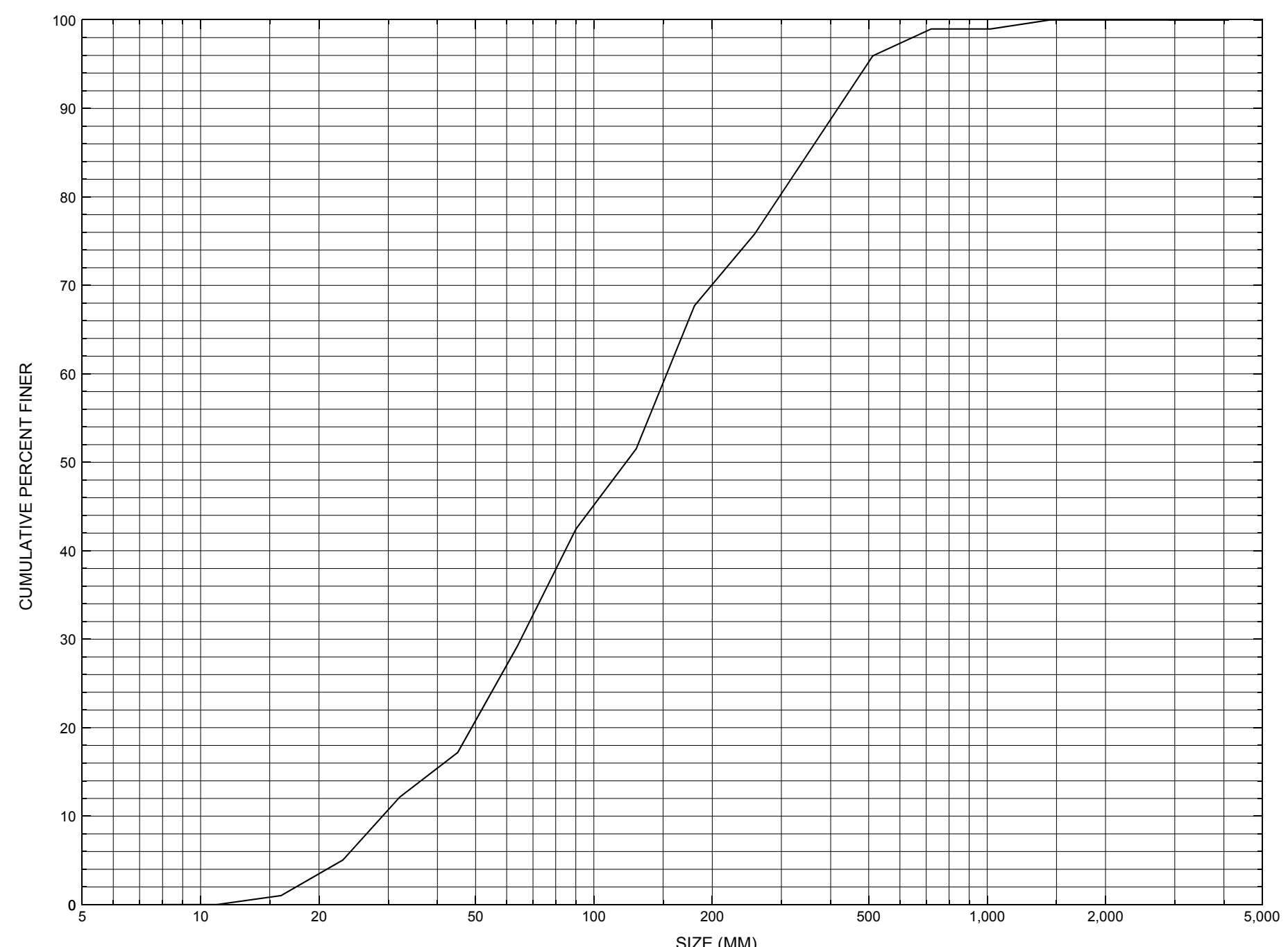

Appendix C. Bed material particle-size distribution for a pebble count in the channel approach of structure NEWFTH00350042, in Newfane, Vermont. 


\section{APPENDIX D: \\ HISTORICAL DATA FORM}




\section{Structure Number NEWFTH00350042}

\section{General Location Descriptive}

Data collected by (First Initial, Full last name) $\underline{\text { M. IVANOFF }}$

Date $(M M / D D / Y Y) \_\mathbf{0 4} / \underline{06} / \underline{95}$

Highway District Number (I - 2; nn) $\mathbf{0 2}$

Town (FIPS place code; I - 4; nnnnn) $\mathbf{4 8 4 0 0}$

Waterway (I - 6) STRATTON HILL BROOK

Route Number TH035

Topographic Map Newfane

Latitude (I - 16; nnnn.n) $\mathbf{4 2 5 6 4}$
County (FIPS county code; I - 3; nnn)

Mile marker (I - 11; nnn.nnn) $\mathbf{0 0 0 0 0 0}$

Road Name (I - 7): -

Vicinity (I - 9) 0.15 MI TO JCT W CL2 TH2

Hydrologic Unit Code: $\mathbf{0 1 0 8 0 1 0 7}$

Longitude (i - 17; nnnnn.n) $\mathbf{7 2 4 3 5}$

\section{Select Federal Inventory Codes}

FHWA Structure Number (I - 8) 10131200421312

Maintenance responsibility $(I-21 ; n n) \quad \mathbf{0 3} \quad$ Maximum span length $(I-48 ; n n n n) \underline{\mathbf{0 0 3 2}}$

Year built (I - 27; YYYY) 1939

Structure length (I - 49; nnnnnn) $\underline{\mathbf{0 0 0 0 3 4}}$

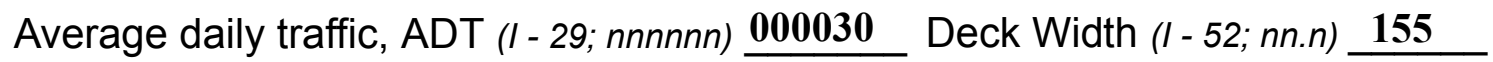

Year of ADT (I - 30; YY) $\mathbf{9 0}$

Channel \& Protection $(I-61 ; n) \underline{5}$

Opening skew to Roadway $(I-34 ; n n) \quad \mathbf{0 0}$

Waterway adequacy $(I-71 ; n)$

Operational status $(I-41 ; X) \underline{P}$

Underwater Inspection Frequency $(I-92 B ; X Y Y) \_\mathbf{N}$

Structure type (I - 43; nnn) $\mathbf{3 0 2}$

Year Reconstructed (I - 106) $\mathbf{0 0 0 0}$

Approach span structure type (I - 44; nnn) $\mathbf{0 0 0}$ Clear span (nnn.n ft) _ _

Number of spans (I - 45; nnn) $\mathbf{0 0 1}$

Vertical clearance from streambed (nnn.n ft) $\underline{\mathbf{0 0 6 . 8}}$

Number of approach spans (I - 46; nnnn) $\mathbf{0 0 0 0}$

Waterway of full opening $\left(n n n . n \mathrm{ft}^{2}\right)$

Comments:

The structural inspection report of $07 / 27 / 94$ indicates the structure is a steel beam type bridge with a timber deck. The abutments appear to be concrete faced laid up stone. They have some areas of minor spalling noted. There is a newer concrete subfooting poured along the bottom of the right abutment. The waterway has a fairly straight alignment through the skewed structure. The streambed consists of stone and boulder material with some gravel deposits. The stone fill protection consists of natural stone and boulder material. 


\section{Bridge Hydrologic Data}

Is there hydrologic data available? $\underline{\mathbf{N}}$ if No, type ctrl-n $h \quad$ VTAOT Drainage area $\left(m i^{2}\right)$ : -

Terrain character:

Stream character \& type: -

Streambed material:

Discharge Data (cfs):

$$
\begin{aligned}
& Q_{2.33}- \\
& Q_{50}-
\end{aligned}
$$

Record flood date $(M M / D D / Y Y)$ :

Estimated Discharge (cfs): Ice conditions (Heavy, Moderate, Light) : -

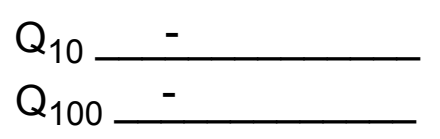

$$
\begin{aligned}
& Q_{25}- \\
& Q_{500}-
\end{aligned}
$$

Water surface elevation $(f t):-$

The stage increases to maximum highwater elevation (Rapidly, Not rapidly):

The stream response is (Flashy, Not flashy):

Describe any significant site conditions upstream or downstream that may influence the stream's stage: -

Watershed storage area (in percent): _ _ \%

The watershed storage area is: - (1-mainly at the headwaters; 2- uniformly distributed; 3-immediatly upstream oi the site)

Water Surface Elevation Estimates for Existing Structure:

\begin{tabular}{|l|l|l|l|l|l|}
\hline Peak discharge frequency & $Q_{2.33}$ & $Q_{10}$ & $Q_{25}$ & $Q_{50}$ & $Q_{100}$ \\
Water surface elevation (ft)) & - & - & - & - & - \\
Velocity (ft/sec) & - & - & - & - & - \\
\hline
\end{tabular}

Long term stream bed changes: -

Is the roadway overtopped below the $\mathrm{Q}_{100}$ ? (Yes, No, Unknown): $\mathbf{U}$ Frequency: Relief Elevation (ft): Discharge over roadway at $Q_{100}\left(f^{3} / \mathrm{sec}\right)$ :

Are there other structures nearby? (Yes, No, Unknown): $\underline{\mathbf{U}}$ Upstream distance (miles): Town: If No or Unknown, type ctrl-n os Highway No. : Structure No. : Year Built:

Clear span (ft): Clear Height $(f t)$ : Full Waterway $\left(f^{2}\right)$ : 
Downstream distance (miles): Town: Year Built:

Highway No. : Structure No. : Structure Type:

Clear span $(f t):$ Clear Height $(f t)$ : Full Waterway $\left(f^{2}\right):$

Comments:

\section{USGS Watershed Data}

Watershed Hydrographic Data

Drainage area $(D A) \underline{1.16}$

Watershed storage (ST)

Bridge site elevation

Main channel length 886

1.98 $10 \%$ channel length elevation $\mathbf{8 6 6}$

Main channel slope

(S) 530.51 $\mathrm{ft} / \mathrm{mi}$ $\%$ $\mathrm{mi}$

Lake/pond/swamp area $\mathbf{0}$ $\mathrm{mi}^{2}$

Headwater elevation $\quad \mathbf{1 8 6 4} \mathrm{ft}$ $\mathrm{ft} \quad 85 \%$ channel length elevation $\mathrm{ft}$

Watershed Precipitation Data

Average site precipitation in Average headwater precipitation in

Maximum 2yr-24hr precipitation event $(124,2)$ in

Average seasonal snowfall (Sn) $\mathrm{ft}$ 


\section{Bridge Plan Data}

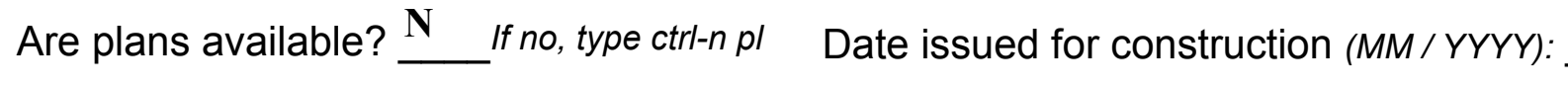

Project Number

Minimum channel bed elevation:

Low superstructure elevation: USLAB DSLAB USRAB DSRAB Benchmark location description:

NO BENCHMARK INFORMATION

Reference Point (MSL, Arbitrary, Other): Datum (NAD27, NAD83, Other):

Foundation Type: 4

If 1: Footing Thickness

If 2: Pile Type: (1-Wood; 2-Steel or metal; 3-Concrete)

If 3 : Footing bottom elevation:

Is boring information available? $\mathbf{N}$ If no, type ctrl-n bi Number of borings taken:

Foundation Material Type: $\mathbf{3}$ (1-regolith, 2-bedrock, 3-unknown)

Briefly describe material at foundation bottom elevation or around piles:

NO FOUNDATION MATERIAL INFORMATION

Comments:

NO PLANS. 


\section{Cross-sectional Data}

Is cross-sectional data available? Yes If no, type ctrl-n xs

Source (FEMA, VTAOT, Other)? VTAOT

The elevation and station measurements are in feet. This cross section was attached to a 7/27/ Comments: 94 bridge inspection report. The elevation coordinate has been made to fit that of this report by the low steel elevations.

\begin{tabular}{|c|c|c|c|c|c|c|c|c|c|c|c|}
\hline Station & $\mathbf{0}$ & 8 & 16 & 24 & 31.17 & 32 & - & - & - & - & - \\
\hline Feature & LAB & - & - & - & - & RAB & - & - & - & - & - \\
\hline $\begin{array}{l}\text { Low chord } \\
\text { elevation }\end{array}$ & 499.11 & 498.85 & 498.58 & 498.32 & 498.08 & 498.06 & - & - & - & - & - \\
\hline $\begin{array}{l}\text { Bed } \\
\text { elevation }\end{array}$ & 496.61 & 492.45 & 491.58 & 491.52 & 492.88 & 492.86 & - & - & - & - & - \\
\hline $\begin{array}{l}\text { Low chord } \\
\text { to bed }\end{array}$ & 2.5 & 6.5 & 7 & 6.8 & 5.2 & 5.2 & - & - & - & - & - \\
\hline Station & - & - & - & - & - & - & - & - & - & - & - \\
\hline Feature & - & - & - & - & - & - & - & - & - & - & - \\
\hline $\begin{array}{l}\text { Low chord } \\
\text { elevation }\end{array}$ & - & - & - & - & - & - & - & - & - & - & - \\
\hline $\begin{array}{l}\text { Bed } \\
\text { elevation }\end{array}$ & - & - & - & - & - & - & - & - & - & - & - \\
\hline $\begin{array}{l}\text { Low chord } \\
\text { to bed }\end{array}$ & - & - & - & - & - & - & - & - & - & - & - \\
\hline
\end{tabular}

Source (FEMA, VTAOT, Other)?

Comments: -

\begin{tabular}{|l|l|l|l|l|l|l|l|l|l|l|l|l|}
\hline Station & - & - & - & - & - & - & - & - & - & - \\
\hline Feature & - & - & - & - & - & - & - & - & - & - \\
\hline $\begin{array}{l}\text { Low chord } \\
\text { elevation }\end{array}$ & - & - & - & - & - & - & - & - & - & - & - \\
\hline $\begin{array}{l}\text { Bed } \\
\text { elevation }\end{array}$ & - & - & - & - & - & - & - & - & - & - \\
\hline $\begin{array}{l}\text { Low chord } \\
\text { to bed }\end{array}$ & - & - & - & - & & - & - & - & - & - & - \\
\hline \begin{tabular}{l} 
Station \\
\hline \begin{tabular}{l} 
Feature \\
\hline
\end{tabular}
\end{tabular}$-$ & - & - & - & - & - & - & - & - & - & - & - & - \\
\hline $\begin{array}{l}\text { Low chord } \\
\text { elevation }\end{array}$ & - & - & - & - & - & - & - & - & - & - \\
\hline $\begin{array}{l}\text { Bed } \\
\text { elevation }\end{array}$ & - & - & - & - & - & - & - & - & - & - \\
\hline $\begin{array}{l}\text { Low chord } \\
\text { to bed }\end{array}$ & - & - & - & - & - & - & - & - & - & - \\
\hline
\end{tabular}




\section{APPENDIX E: \\ LEVEL I DATA FORM}


U. S. Geological Survey

Bridge Field Data Collection and Processing Form

Qa/Qc Check by: EW Date: $10 / 30 / 96$

\section{Structure Number}

NEWFTH00350042 Date: $\underline{11 / 1 / 96}$ Computerized by: $\mathbf{E W}$ Date: 2 /9/98

\section{A. General Location Descriptive}

1. Data collected by (First Initial, Full last name) M. IVANOFF

2. Highway District Number $\mathbf{0 2}$

Mile marker 000000

County WINDHAM (025)

Waterway (l - 6) STRATTON HILL BROOK

Route Number TH 35

Town NEWFANE (48400)

Road Name STRATTON HILL ROAD

Hydrologic Unit Code: $\mathbf{0 1 0 8 0 1 0 7}$

3. Descriptive comments:

Bridge 42 is located 0.15 miles from the junction with Town Highway 2.

\section{B. Bridge Deck Observations}
4. Surface cover... LBUS 6
RBUS 6
LBDS 6
RBDS 6
Overall 6

(2b us,ds,lb,rb: 1- Urban; 2- Suburban; 3- Row crops; 4- Pasture; 5- Shrub- and brushland; 6- Forest; 7- Wetland)
5. Ambient water surface... US 2
UB 2
DS 2
(1- pool; 2- riffle)

6. Bridge structure type 1 (1- single span; 2- multiple span; 3- single arch; 4- multiple arch; 5-cylindrical culvert; 6- box culvert; or 7- other)
7. Bridge length $\mathbf{3 4}$
(feet)
Span length $\underline{\mathbf{3 2}}$
(feet)
Bridge width 15.5 (feet)

\section{Road approach to bridge:}
8. LB $\underline{2}$ RB 1
( 0 even, 1- lower, 2- higher)
9. LB_
RB $\underline{2}$
(1-Paved, 2- Not paved)

10. Embankment slope (run / rise in feet / foot)

US left

US right

\begin{tabular}{|c|c|c|c|}
\hline \multicolumn{2}{|c|}{ Protection } & \multirow{2}{*}{ 13.Erosion } & 14.Severity \\
\hline 11.Type & 12.Cond. & $\mathbf{0}$ & - \\
\hline $\mathbf{0}$ & - & $\mathbf{0}$ & - \\
\hline $\mathbf{0}$ & - & $\mathbf{0}$ & - \\
\hline $\mathbf{5}$ & $\mathbf{1}$ & $\mathbf{0}$ & - \\
\hline $\mathbf{1}$ & $\mathbf{1}$ & $\mathbf{0}$ & - \\
\hline
\end{tabular}

Bank protection types: 0- none; 1- < 12 inches,

2- < 36 inches; 3- < 48 inches;

4- < 60 inches; 5- wall / artificial levee

Bank protection conditions: 1- good; 2- slumped;

3- eroded; 4- failed

Erosion: 0 - none; 1- channel erosion; 2 -

road wash; 3- both; 4- other

Erosion Severity: 0 - none; 1- slight; 2- moderate; 3- severe

\section{Channel approach to bridge (BF):}

15. Angle of approach: $\mathbf{2 0}$

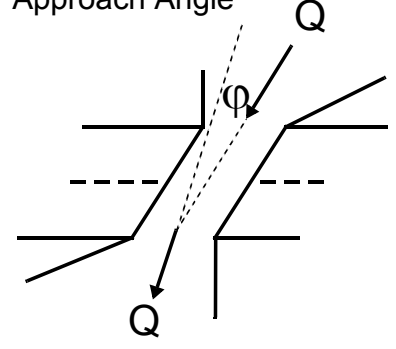

17. Channel impact zone 1:

Where? RB (LB, RB)

Range? 0 feet US

Channel impact zone 2:

Where? (LB, RB)

Range? feet (US, UB, DS) to feet

16. Bridge skew: $\mathbf{2 0}$ Bridge Skew Angle

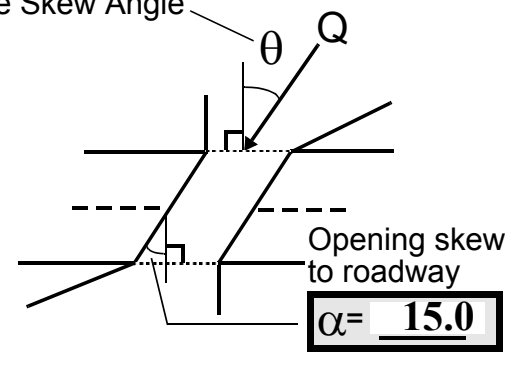

\section{Exist? $\underline{\mathbf{Y}}(\mathrm{Y}$ or $N)$}

Severity $\mathbf{0}$

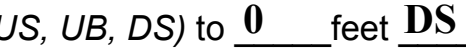

Exist? $\mathbf{N}(Y$ or $N)$

Severity

Impact Severity: 0- none to very slight; 1- Slight; 2- Moderate; 3- Severe 
18. Bridge Type: 1a

1a- Vertical abutments with wingwalls

1 b- Vertical abutments without wingwalls

2- Vertical abutments and wingwalls, sloping embankment

Wingwalls parallel to abut. face

3- Spill through abutments

4- Sloping embankment, vertical wingwalls and abutments

Wingwall angle less than $90^{\circ}$.

1a with wingwalls

19. Bridge Deck Comments (surface cover variations, measured bridge and span lengths, bridge type variations, approach overflow width, etc.)

7: Values are from VTAOT database. Site visit measurements where the same as VT AOT values.

\section{Upstream Channel Assessment}

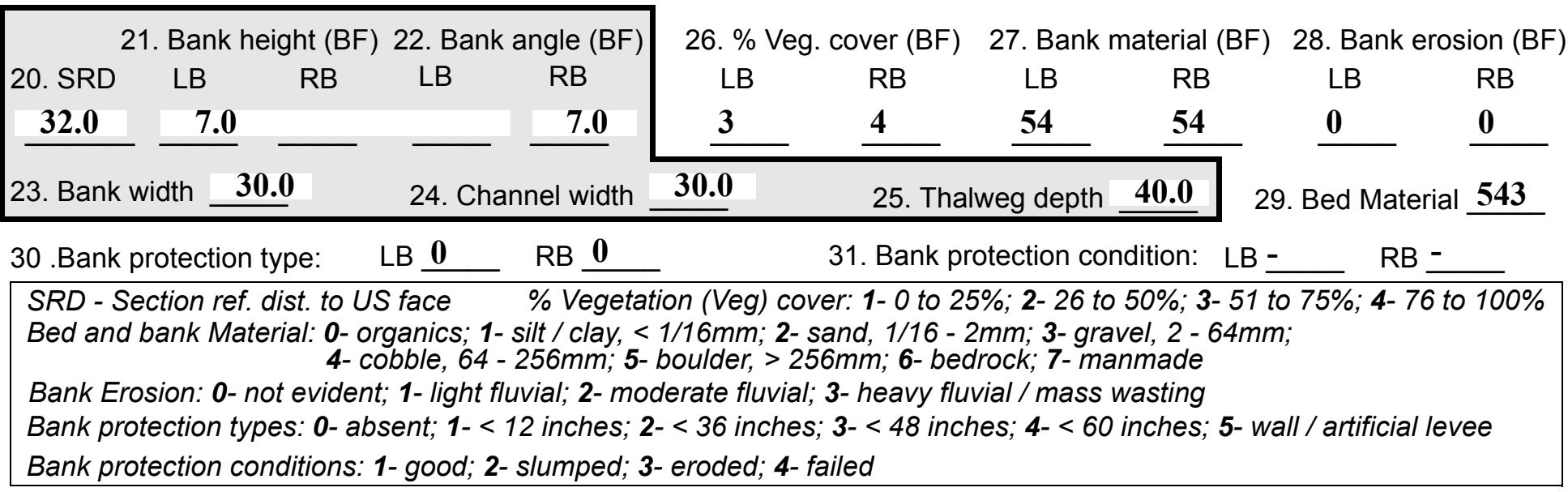

32. Comments (bank material variation, minor inflows, protection extent, etc.):

Bedrock extends across channel bed 120 feet upstream. 
33.Point/Side bar present? $\mathbf{N}(Y$ or $N$. if $N$ type ctrl-n pb)34. Mid-bar distance: -

35. Mid-bar width:

36. Point bar extent: feet (US, UB) to feet (US, UB, DS) positioned $\%$ LB to $\% \mathrm{RB}$

37. Material:

38. Point or side bar comments (Circle Point or Side; Note additional bars, material variation, status, etc.):

NO POINT BARS

39. Is a cut-bank present? $\underline{\mathbf{N}}$ (Y or if $\mathrm{N}$ type ctrl-n cb)

40. Where? (LB or $R B)$

41. Mid-bank distance: -

42. Cut bank extent: feet (US, UB) to feet (US, UB, DS)

43. Bank damage: (1- eroded and/or creep; 2- slip failure; 3- block failure)

44. Cut bank comments (eg. additional cut banks, protection condition, etc.):

NO CUT BANKS

45. Is channel scour present? $\mathbf{N}$ ( $Y$ or if $N$ type ctrl-n cs)

47. Scour dimensions: Length Width Depth : -

46. Mid-scour distance: -

48. Scour comments (eg. additional scour areas, local scouring process, etc.):

NO CHANNEL SCOUR

49. Are there major confluences? $\mathbf{N}$ ( $Y$ or if $N$ type ctrl-n $m c$ )

51. Confluence 1: Distance 52. Enters on (LB or $R B)$ Confluence 2: Distance Enters on (LB or $R B)$

54. Confluence comments (eg. confluence name):

NO MAJOR CONFLUENCES

\section{Under Bridge Channel Assessment}

55. Channel restraint (BF)? LB 2

\begin{tabular}{|c|c|c|}
\hline 56. & t (BF) & 57 Angle (BF) \\
\hline LB & $\mathrm{RB}$ & LB \\
\hline
\end{tabular}

58. Bank width (BF) (1- natural bank; 2- abutment; 3- artificial levee) ...

\begin{tabular}{|c|c|c|c|}
\hline \multicolumn{2}{|c|}{ 61. Material (BF) } & \multicolumn{2}{|c|}{ 62. Erosion (BF) } \\
\hline LB & RB & LB & $\mathrm{RB}$ \\
\hline 2 & 7 & 7 & - \\
\hline
\end{tabular}

59. Channel width -

60. Thalweg depth $\mathbf{9 0 . 0}$

63. Bed Material -

Bed and bank Material: 0- organics; 1- silt / clay, < 1/16mm; 2- sand, 1/16 - 2mm; 3- gravel, 2 - 64mm; 4- cobble, 64 - 256mm; 5- boulder, > 256mm; 6- bedrock; 7- manmade

Bank Erosion: 0- not evident; 1- light fluvial; 2- moderate fluvial; 3- heavy fluvial / mass wasting

64. Comments (bank material variation, minor inflows, protection extent, etc.):

543 
65. Debris and Ice Is there debris accumulation?

$(Y$ or $N)$ 66. Where? $\underline{Y}$

(1- Upstream; 2- At bridge; 3- Both)

67. Debris Potential 1 (1-Low; 2-Moderate; 3- High)

68. Capture Efficiency 2

(1-Low; 2- Moderate; 3- High)

69. Is there evidence of ice build-up? 1 ( 1 or $N)$

Ice Blockage Potential $\mathbf{N}$

(1- Low; 2- Moderate; 3- High)

70. Debris and Ice Comments:

1

Trees overhang the channel and debris exists along the channel banks.

\begin{tabular}{|l|c|c|c|c|c|c|c|c|}
\hline Abutments & $\begin{array}{c}\text { 71. Attack } \\
\angle \text { (BF) }\end{array}$ & $\begin{array}{c}72 . \text { Slope } \angle \\
\text { (Qmax) }\end{array}$ & $\begin{array}{c}\text { 73. Toe } \\
\text { loc. (BF) }\end{array}$ & $\begin{array}{c}\text { 74. Scour } \\
\text { Condition }\end{array}$ & $\begin{array}{c}75 . \text { Scour } \\
\text { depth }\end{array}$ & $\begin{array}{c}\text { 76. Exposure } \\
\text { depth }\end{array}$ & 77. Material & 78. Length \\
\hline LABUT & & $\mathbf{0}$ & $\mathbf{9 0}$ & $\mathbf{0}$ & $\mathbf{0}$ & - & - & $\mathbf{9 0 . 0}$ \\
\hline RABUT & $\mathbf{1}$ & $\mathbf{1 0}$ & $\mathbf{9 0}$ & & & $\mathbf{2}$ & $\mathbf{2}$ & $\mathbf{2 3 . 0}$ \\
\hline
\end{tabular}

Pushed: $L B$ or RB

Toe Location (Loc.): 0- even, 1- set back, 2- protrudes

Scour cond.: 0- not evident; 1- evident (comment); 2- footing exposed; 3-undermined footing; 4- piling exposed; 5- settled; 6- failed

Materials: 1- Concrete; 2- Stone masonry or drywall; 3- steel or metal; 4- wood

79. Abutment comments (eg. undermined penetration, unusual scour processes, debris, etc.):

0

1.5

1

Historical form notes footing added to base of the right abutment. The right abutment footing maximum exposure is $\mathbf{1 . 5}$ feet at the downstream bridge face.

80. Wingwalls:

Exist? Material? Scour Scour Exposure 81. Condition? depth? depth?

USLWW:

23.0

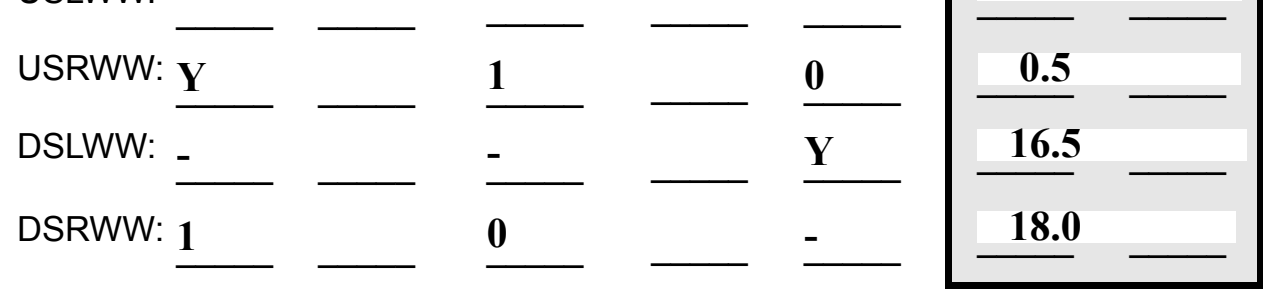

Wingwall materials: 1- Concrete; 2- Stone masonry or drywall; 3- steel or metal; 4- wood

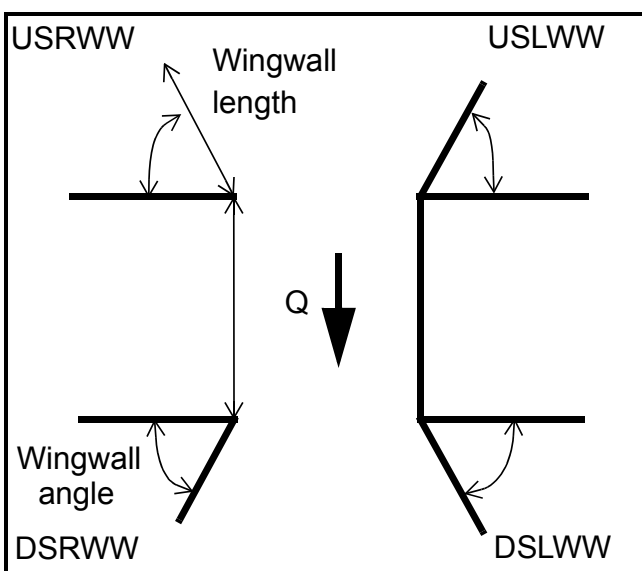

82. Bank / Bridge Protection:

\begin{tabular}{|l|l|l|l|l|l|l|l|l|}
\hline Location & USLWW & USRWW & LABUT & RABUT & LB & RB & DSLWW & DSRWW \\
\hline Type & - & - & $\mathbf{N}$ & - & - & - & - & - \\
\hline Condition & $\mathbf{N}$ & - & - & - & - & - & - & - \\
\hline Extent & - & - & - & $\mathbf{0}$ & $\mathbf{0}$ & $\mathbf{0}$ & $\mathbf{0}$ & $\mathbf{0}$ \\
\hline
\end{tabular}

Bank / Bridge protection types: 0- absent; 1- < 12 inches; 2- < 36 inches; 3- < 48 inches; 4- < 60 inches; 
83. Wingwall and protection comments (eg. undermined penetration, unusual scour processes, etc.):

-
-
-
-
-
-
-
-
-
-

\section{Piers:}

84. Are there piers? _ (Y or if $N$ type ctrl-n pr)

\begin{tabular}{|l|l|l|l|l|l|l|l|}
\hline \multirow{2}{*}{$\begin{array}{l}85 . \\
\text { Pier no. }\end{array}$} & \multicolumn{3}{|c|}{ width (w) feet } & \multicolumn{3}{c|}{ elevation (e) feet } \\
\cline { 2 - 9 } & w1 & w2 & w3 & e@w1 & e@w2 & e@w3 \\
\hline Pier 1 & & $\mathbf{2 . 5}$ & $\mathbf{9 . 0}$ & $\mathbf{3 5 . 0}$ & $\mathbf{1 1 0 . 0}$ & - \\
\hline Pier 2 & - & - & - & - & - & - \\
\hline Pier 3 & - & - & - & - & - & - \\
\hline Pier 4 & - & - & - & - & - & - \\
\hline
\end{tabular}

\begin{tabular}{|l|l|l|l|l|}
\hline Level 1 Pier Descr. & 1 & \multicolumn{1}{|c|}{2} & 3 & \multicolumn{1}{|c|}{} \\
\hline 86. Location (BF) & & - & - & - \\
\hline 87. Type & & - & - & - \\
\hline 88. Material & & - & - & - \\
\hline 89. Shape & & - & - & - \\
\hline 90. Inclined? & & - & - & - \\
\hline 91. Attack $\angle$ (BF) & & - & - & - \\
\hline 92. Pushed & & - & - & - \\
\hline 93. Length (feet) & - & - & - & - \\
\hline 94. \# of piles & & - & - & - \\
\hline 95. Cross-members & & - & - & - \\
\hline 96. Scour Condition & & - & - & - \\
\hline 97. Scour depth & $\mathbf{N}$ & - & - & - \\
\hline 98. Exposure depth & - & - & - & - \\
\hline
\end{tabular}

LFP, LTB, LB, MCL, MCM, MCR, RB, RTB, RFP

1- Solid pier, 2- column, 3- bent

1-Wood; 2-concrete; 3- metal; 4- stone

1- Round; 2- Square; 3- Pointed

Y-yes; $N-$ no

$L B$ or $R B$

0- none; 1- laterals; 2- diagonals; 3- both

0- not evident; 1- evident (comment);

2- footing exposed; 3- piling exposed;

4- undermined footing; 5- settled; 6- failed 
99. Pier comments (eg. undermined penetration, protection and protection extent, unusual scour processes, etc.):

-
-
-
-
-
-
-
-
-
-

100.

\section{E. Downstream Channel Assessment}

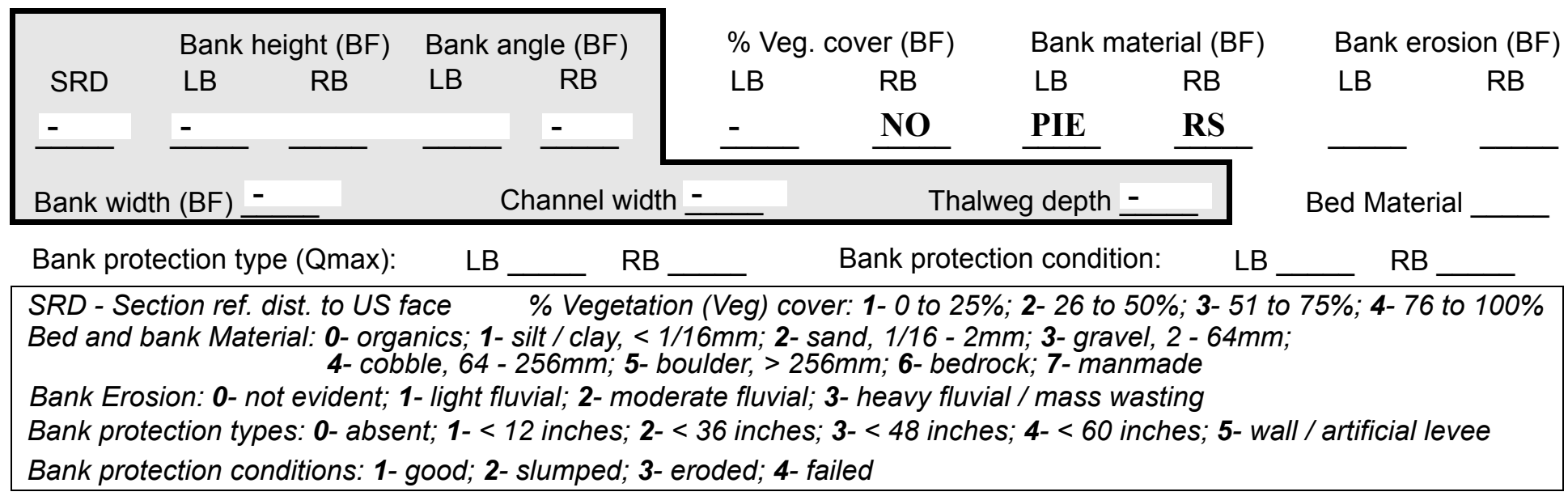

Comments (eg. bank material variation, minor inflows, protection extent, etc.):

3
4
54
54
1
0
543
1
0
1
-

Left bank protection extends from the downstream bridge face to 8 feet downstream, and 8 feet (horizontally) into the channel.

101. Is a drop structure present? __ (Y or $N$, if $N$ type ctrl-n ds) 102. Distance: __ feet
103. Drop: - feet
104. Structure material:
(1- steel sheet pile; 2- wood pile; 3-concrete; 4- other)

105. Drop structure comments (eg. downstream scour depth): 
Point bar extent: feet

(US, UB, DS) to $\underline{\mathbf{N}}$ feet (US, UB, DS)

DS) positioned \%LB to DR \%RB

Material: $\mathbf{O P}$

Point or side bar comments (Circle Point or Side; note additional bars, material variation, status, etc.):

\section{STRUCTURE}

Is a cut-bank present? (Y or if $N$ type ctrl- $n$ cb) Where? (LB or $R B)$

Mid-bank distance: $\underline{\mathbf{Y}}$

Cut bank extent: $\underline{66}$ feet $\underline{8}$ (US, UB, DS) to 46 feet $\underline{\text { DS }}$ (US, UB, DS)

Bank damage: 100 (1- eroded and/or creep; 2- slip failure; 3- block failure)

Cut bank comments (eg. additional cut banks, protection condition, etc.):

DS

$\mathbf{5 0}$

100

43

$\underline{\text { Is channel scour present? }}$ Co (Y or if N type ctrl-n cs) Mid-scour distance: $\underline{\text { bble }}$ Scour dimensions: Length and Width grav Depth: el Positioned poi \%LB to $\underline{\text { nt }}$ \%RB Scour comments (eg. additional scour areas, local scouring process, etc.):

bar.

Are there major confluences? $\mathbf{Y}$ ( $Y$ or if $N$ type ctrl-n $m c$ )

Confluence 1: Distance 65

Confluence 2: Distance $\underline{\mathbf{8 0}}$

Enters on $\underline{\mathbf{3 3}}$ ( $L B$ or $R B)$

Enters on DS (LB or RB)

Confluence comments (eg. confluence name):
How many? $\underline{\mathbf{L B}}$

Type DS (1- perennial; 2- ephemeral)

Type 1 (1- perennial; 2- ephemeral)

\section{F. Geomorphic Channel Assessment}

107. Stage of reach evolution

1- Constructed

2- Stable

3- Aggraded

4- Degraded

5- Laterally unstable

6- Vertically and laterally unstable 



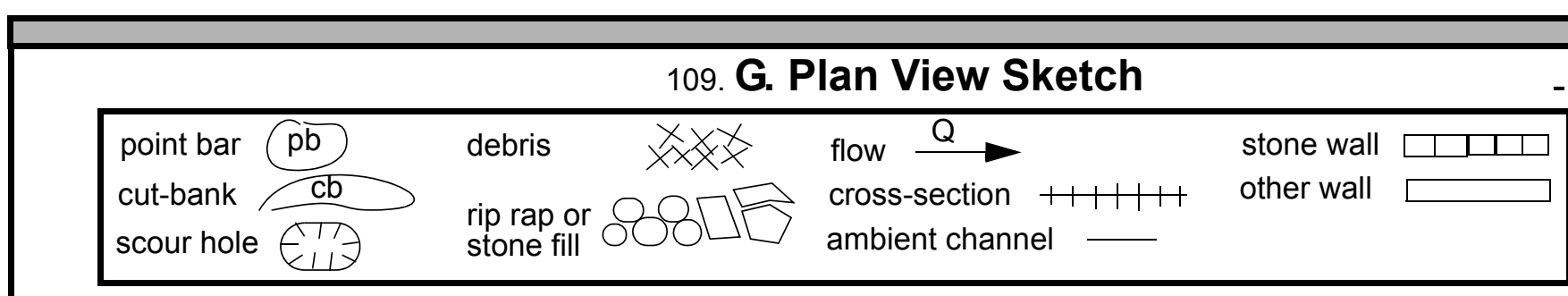


APPENDIX F:

SCOUR COMPUTATIONS 


\begin{tabular}{|c|c|c|c|}
\hline Structure Number: NEWFTH00350042 & & Town: & NEWFANE \\
\hline Road Number: $\quad$ TH 35 & & County: & WINDHAM \\
\hline Stream: STRATTON HILL BROOK & & & \\
\hline Initials ECW & Checked: & $\mathrm{EB}$ & \\
\hline ttion scour, live & ed or $\mathrm{c}$ & ear wa & \\
\hline $\begin{array}{l}\text { Critical Velocity of Bed Material } \\
\text { VC=11.21*y1^0.1667*D50^0.33 with Ss } \\
\text { (Richardson and Davis, 1995, p. 28, }\end{array}$ & $\begin{array}{l}\text { converted } \\
=2.65 \\
\text { eq. } 16)\end{array}$ & to Engl & sh units \\
\hline Approach Section & & & \\
\hline Characteristic & $100 \mathrm{yr}$ & $500 \mathrm{yr}$ & other Q \\
\hline Total discharge, cfs & 440 & 680 & 0 \\
\hline Main Channel Area, ft2 & 51 & 69 & 0 \\
\hline Left overbank area, ft2 & 0 & 0 & 0 \\
\hline Right overbank area, ft2 & 0 & 0 & 0 \\
\hline Top width main channel, ft & 23 & 23 & 0 \\
\hline Top width L overbank, ft & 0 & 0 & 0 \\
\hline Top width $\mathrm{R}$ overbank, ft & 0 & 0 & 0 \\
\hline D50 of channel, ft & 0.396 & 0.396 & 0 \\
\hline D50 left overbank, ft & -- & -- & -- \\
\hline D50 right overbank, ft & -- & -- & -- \\
\hline Y1, average depth, MC, ft & 2.2 & 3.0 & ERR \\
\hline Y1, average depth, LOB, ft & $\mathrm{ERR}$ & $\mathrm{ERR}$ & ERR \\
\hline Y1, average depth, ROB, ft & $\mathrm{ERR}$ & ERR & ERR \\
\hline Total conveyance, approach & 1589 & 2494 & 0 \\
\hline Conveyance, main channel & 1589 & 2494 & 0 \\
\hline Conveyance, LOB & 0 & 0 & 0 \\
\hline Conveyance, ROB & 0 & 0 & 0 \\
\hline Percent discrepancy, conveyance & 0.0000 & 0.0000 & $\mathrm{ERR}$ \\
\hline Qm, discharge, MC, cfs & 440.0 & 680.0 & ERR \\
\hline Q1, discharge, LOB, Cfs & 0.0 & 0.0 & ERR \\
\hline Qr, discharge, ROB, cfs & 0.0 & 0.0 & $\mathrm{ERR}$ \\
\hline Vm, mean velocity $\mathrm{MC}$, ft/s & 8.6 & 9.9 & ERR \\
\hline Vl, mean velocity, LOB, ft/s & ERR & ERR & ERR \\
\hline Vr, mean velocity, ROB, ft/s & ERR & ERR & ERR \\
\hline Vc-m, crit. velocity, $\mathrm{MC}$, ft/s & 9.4 & 9.9 & $\mathrm{~N} / \mathrm{A}$ \\
\hline Vc-l, crit. velocity, LOB, ft/s & $\mathrm{ERR}$ & $\mathrm{ERR}$ & $\mathrm{ERR}$ \\
\hline VC-r, crit. velocity, ROB, ft/s & ERR & ERR & ERR \\
\hline Results & & & \\
\hline Live-bed(1) or Clear-Water(0) Contr & action Sc & our? & \\
\hline Main Channel & 0 & 0 & $\mathrm{~N} / \mathrm{A}$ \\
\hline Left Overbank & $\mathrm{N} / \mathrm{A}$ & $\mathrm{N} / \mathrm{A}$ & $\mathrm{N} / \mathrm{A}$ \\
\hline Right Overbank & $\mathrm{N} / \mathrm{A}$ & $\mathrm{N} / \mathrm{A}$ & $\mathrm{N} / \mathrm{A}$ \\
\hline
\end{tabular}


Clear water Contraction Scour in MAIN CHANNEL

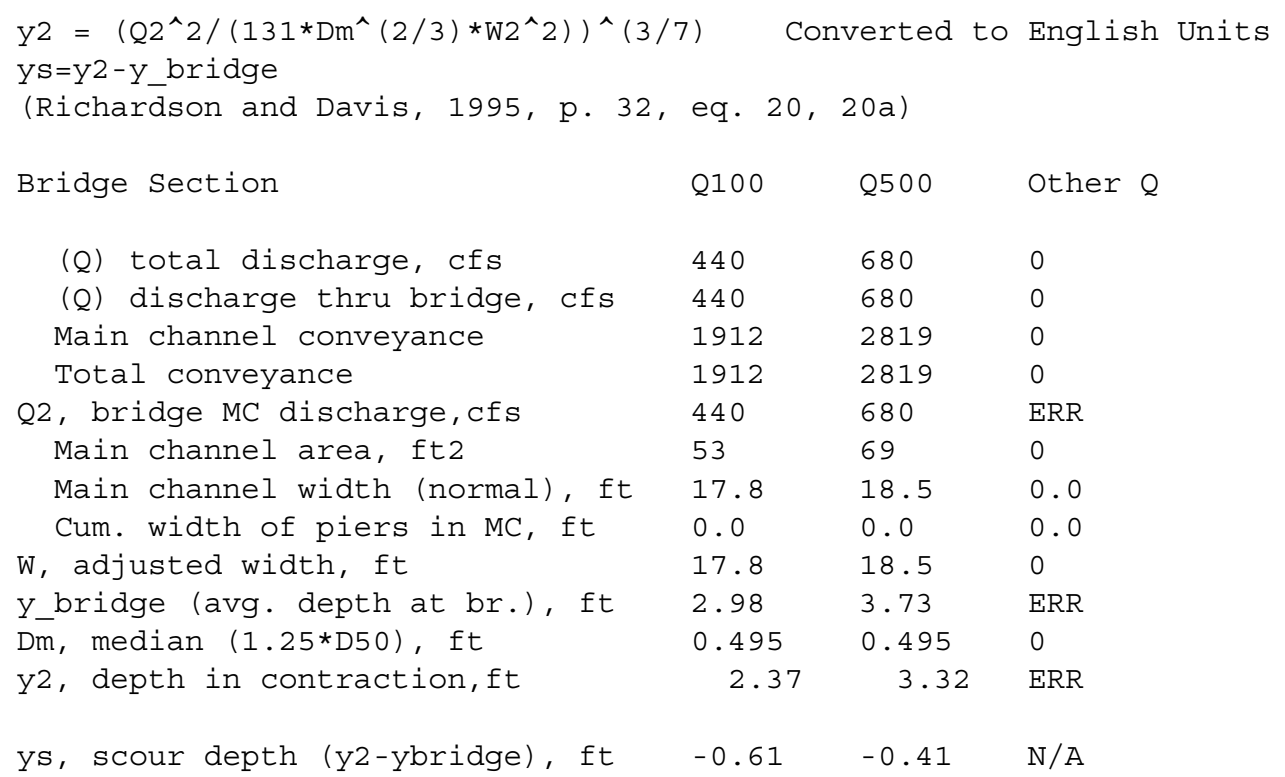

\begin{tabular}{|c|c|c|c|}
\hline \multirow{2}{*}{\multicolumn{4}{|c|}{ Armoring }} \\
\hline & & & \\
\hline \multirow{2}{*}{\multicolumn{4}{|c|}{$\begin{array}{l}\mathrm{DC}=\left[\left(1.94 * \mathrm{~V}^{\wedge} 2\right) /(5.75 * \log (12.27 * \mathrm{y} / \mathrm{D} 90))^{\wedge} 2\right] /[0.03 *(165-62.4)] \\
\text { Depth to Armoring }=3 *(1 / \mathrm{PC}-1)\end{array}$}} \\
\hline & & & \\
\hline (Federal Highway Administration, 199 & 93) & & \\
\hline Downstream bridge face property & $100-y r$ & $500-y r$ & Other $Q$ \\
\hline Q, discharge thru bridge $\mathrm{MC}$, cfs & 440 & 680 & $\mathrm{~N} / \mathrm{A}$ \\
\hline Main channel area (DS), ft2 & 53 & 69 & 0 \\
\hline Main channel width (normal), ft & 17.8 & 18.5 & 0.0 \\
\hline Cum. width of piers, ft & 0.0 & 0.0 & 0.0 \\
\hline Adj. main channel width, ft & 17.8 & 18.5 & 0.0 \\
\hline D90, ft & 1.3646 & 1.3646 & 0.0000 \\
\hline D95, ft & 1.6245 & 1.6245 & 0.0000 \\
\hline Dc, critical grain size, ft & 0.6446 & 0.7956 & ERR \\
\hline Pc, Decimal percent coarser than DC & 0.303 & 0.255 & 0.000 \\
\hline to armorin & 4.45 & 6.98 & ERR \\
\hline
\end{tabular}


Abutment Scour

Froehlich's Abutment Scour

$\mathrm{Ys} / \mathrm{Y} 1=2.27 * \mathrm{~K} 1 * \mathrm{~K} 2 *\left(\mathrm{a}^{\prime} / \mathrm{Y} 1\right) \wedge 0.43 * \mathrm{Fr} 1 \wedge 0.61+1$

(Richardson and Davis, 1995, p. 48, eq. 28)

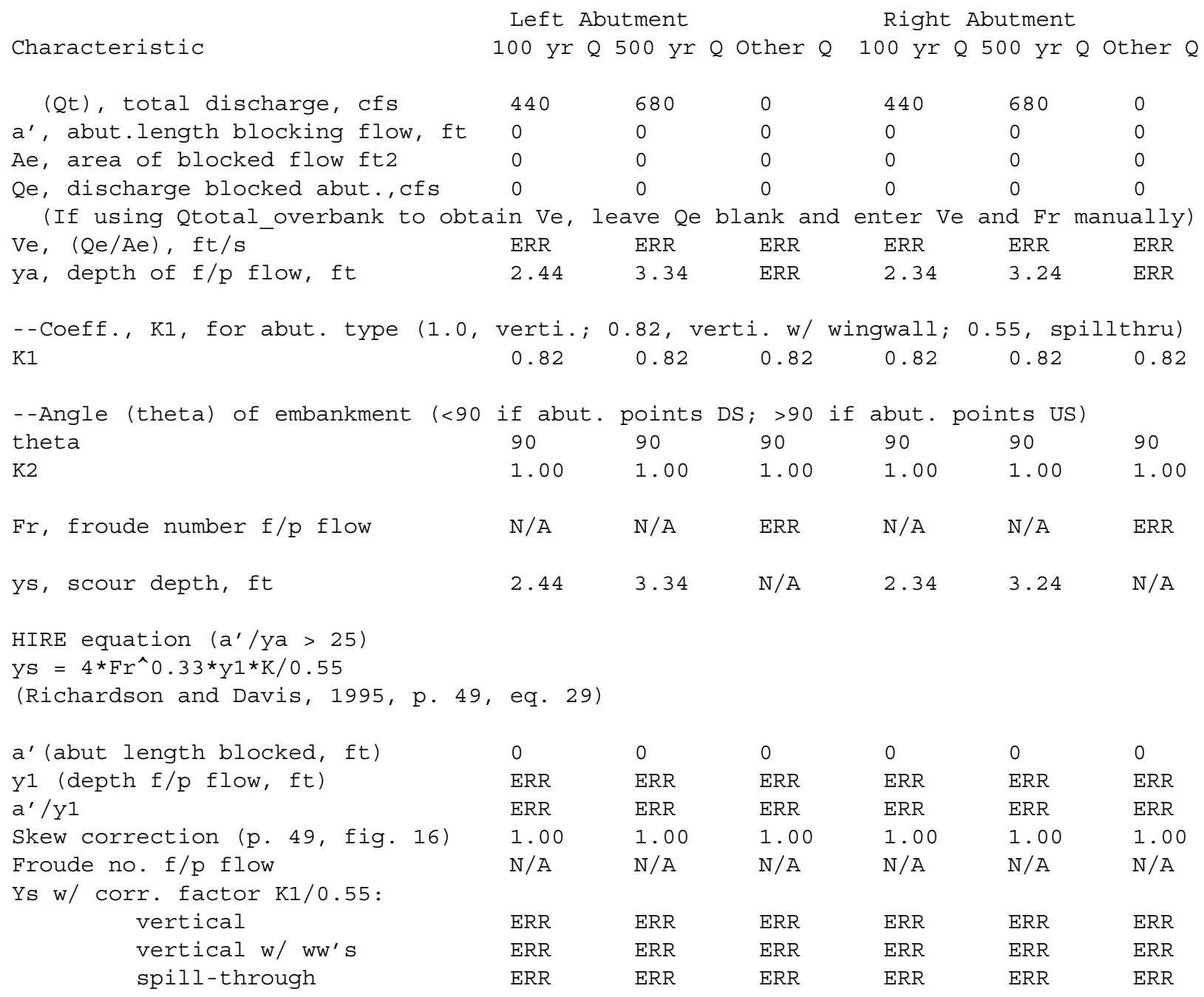






